\title{
Technical guidelines for head and neck cancer IMRT on behalf of the Italian association of radiation oncology - head and neck working group
}

\author{
Anna Merlotti ${ }^{1 \dagger}$, Daniela Alterio ${ }^{2 \dagger}$, Riccardo Vigna-Taglianti ${ }^{3 \dagger}$, Alessandro Muraglia ${ }^{4 \dagger}$, Luciana Lastrucci ${ }^{5 \dagger}$, \\ Roberto Manzo ${ }^{6 \dagger}$, Giuseppina Gambaro ${ }^{7 \dagger}$, Orietta Caspiani ${ }^{8 \dagger}$, Francesco Miccichè ${ }^{9 \dagger}$, Francesco Deodato ${ }^{10 \dagger}$, \\ Stefano Pergolizzi ${ }^{11 \dagger}$, Pierfrancesco Franco ${ }^{12 \dagger}$, Renzo Corvò ${ }^{13 \dagger}$, Elvio G Russi ${ }^{3^{* \dagger}}$ and Giuseppe Sanguineti ${ }^{14 \dagger}$
}

\begin{abstract}
Performing intensity-modulated radiotherapy (IMRT) on head and neck cancer patients (HNCPs) requires robust training and experience. Thus, in 2011, the Head and Neck Cancer Working Group (HNCWG) of the Italian Association of Radiation Oncology (AIRO) organized a study group with the aim to run a literature review to outline clinical practice recommendations, to suggest technical solutions and to advise target volumes and doses selection for head and neck cancer IMRT. The main purpose was therefore to standardize the technical approach of radiation oncologists in this context. The following paper describes the results of this working group. Volumes, techniques/strategies and dosage were summarized for each head-and-neck site and subsite according to international guidelines or after reaching a consensus in case of weak literature evidence.
\end{abstract}

\section{Introduction}

Performing intensity-modulated radiotherapy (IMRT) in head and neck cancer patients (HNCPs) requires training [1] and experience. For example, in the 02-02 Trans Tasman Radiation Oncology Group (TROG) trial, comparing cisplatin (P) and radiotherapy (RT) with or without tirapazamine, a major quality defect of the irradiation approach in terms of dose and target volume selection and delineation was found in $12 \%$ of patients and was associated with a $24 \%$ lower locoregional control rate at 2 years [2]. Hence, in 2011, the Head and Neck Cancer Working Group (HNCWG) of the Italian Association of Radiation Oncology (AIRO) organized a study group to outline clinical practice recommendations regarding techniques, treatment volumes and doses to be employed during head and neck IMRT. The main purpose was to standardize technical approaches of professionals participating into AIRO head and neck cancer trials.

\footnotetext{
* Correspondence: elviorussi@gmail.com

${ }^{\dagger}$ Equal contributors

${ }^{3}$ Radioterapia Az. Ospedaliera S. Croce e Carle-Cuneo, via M. Coppino 26 12100, Cuneo, Italy

Full list of author information is available at the end of the article
}

\section{Material and methods}

The first participants (AM, DA, AM, LL, RM, GG, OC, FM, FD and RC) were chosen on a voluntary basis among the HNCWG members. The group was coordinated by an expert head and neck radiation oncologist (RC). Each member was in charge of a specific topic. At the end of the first draft (February 2012) the whole document was reviewed by all the HNCWG members in order to discuss critical issues and to homogenize the manuscript structure. The revised draft was again reviewed by 5 radiation oncologists with particular expertise in head and neck IMRT (RVT, PF, SP, ER and GS).

\section{General aspects}

Treatment strategy

RT is one of the mainstay treatment options for head and neck cancers (HNCs), along with chemotherapy (ChT) and surgery (S). In general, $\mathrm{RT} \pm \mathrm{ChT}$ is the preferred approach for head and neck squamous cell carcinomas (HN-SCC) whenever organ preservation is desired or the tumor is unresectable at presentation (cT4b) or the patient is considered not amenable to surgery. For early T-stage lesions (cT1 and selected cT2) without 
lymph nodes involvement (cN0), treatment should be monomodal (RT vs $\mathrm{S}$ ), while for locally advanced disease (cT3-cT4 or any $\mathrm{T}, \mathrm{cN}+$ ), treatment is usually multimodal ( $\mathrm{S}$ followed by $\mathrm{RT} \pm \mathrm{ChT}$ vs RT and concomitant $\mathrm{ChT} \pm \mathrm{S}$ ). Concomitant ChT (usually platinum-based) has been shown to increase overall survival (OS) in stage III and IV disease over RT alone [3]. Recently published long-term results of the RTOG 91-11 trial in larynx cancer failed to show such an advantage over sequential ChTRT because of an increased number of non-cancer-related deaths in the concomitant arm, suggesting a higher longterm toxicity rate for ChT-RT [4]. Induction and adjuvant ChT are less effective than concomitant ChT [3,5]. However, within an organ preservation strategy, induction ChT may become an option to select responders who might potentially benefit from an organ preservation approach, driving eventual further treatments ( $\mathrm{S}$ vs $\mathrm{RT}$ ) on the basis of response to neoadjuvant ChT [6,7]. Recent published trials found no benefit from the addition of Taxotere(T)Platinum (P)-5Fluorouracil(F) induction ChT to concomitant ChT/RT or cetuximab-RT compared to concomitant ChT/RT or RT alone [8-10]. Another alternative to concomitant ChT is cetuximab, an epidermal growth factor receptor inhibitor, which, combined to RT, has been shown to provide a better OS than RT alone in HN-SCC [11]. However, Erbitux has never been tested against the standard treatment (concomitant platinum-based ChTRT) and consequently its role is somewhat unclear. Moreover, when Erbitux was added to concomitant ChT-RT, no additional benefit was found [12]. After concomitant ChT-RT, S is usually reserved for eventual locoregional disease persistence. Regarding neck management, most Institutions nowadays use FDG-PET/CT at 10-12 weeks to select patients at risk of for residual nodal disease [13]. The decision to add adjuvant treatments after upfront surgery is made once the pathology report is available. RT is usually added for high risk features including positive resection margins (PRMs), advanced T stage (selected $\mathrm{pT} 3$ and all $\mathrm{pT} 4$ ), perineural invasion, lymph-vascular invasion, any nodal stage higher than pN1, and extra-capsular lymph-nodal extension (ECE); ChT is added for PRM and ECE. Therefore, treatment is usually multidisciplinary and any decision should be discussed within the tumor board involving all specialties. Aspects such as nutrition, oral care and restoration/preservation of swallowing and phonatory function (speech therapy) are also important and should be considered whenever feasible.

\section{IMRT (Intensity-Modulated Radiation Therapy)}

Though few Institutions pioneered IMRT for HN-SCC during mid-90s, this technique has become widespread during the last decade. The aim of IMRT is to achieve more conformal dose distribution over standard 3D conformal RT (3DCRT) and this in turn allows for better sparing of normal structures (i.e. parotid glands). This potentially translates into fewer late side effects (xerostomia) and improved quality of life [14]. With IMRT, the physician identifies the target volumes(s) and the organs at risk (OARs) appropriate for a given clinical condition. The dose to the target is usually proportional to the estimated tumour burden (Table 1 and Figure 1).

It should be noted that the maximum prescribed dose has empirically evolved as the highest tolerated dose taking into account the surrounding normal structures. A 'definitive' treatment typically includes 2-3 dose levels within the same patient. Using IMRT a different dose to different targets can be delivered with sequential plans (as for 3DCRT) or with a simultaneous integrated boost (SIB). It has been shown that the latter approach provides better dose conformity compared to several consecutive plans [15]. When a single plan is prescribed, CTV1 receives both a higher total dose and a higher dose/fraction (d./f.) compared to the other CTVs. This results in an even higher biologically equivalent dose (BED) compared to other CTVs. However, since all dose levels are delivered throughout the same number of fractions, targets must receive different fractionations.

Two solutions have been proposed [16] (see Table 1). The first approach is to maintain conventionally fractionated doses to the highest dose CTV (1.8-2 Gy per fraction) (Table 1) whereas the elective targets receive a lower d./f. (1.6-1.8 Gy). The choice of the latter is made taking into consideration the normalized total dose in 2 Gy fractions (NTD). The second strategy is to deliver a slightly hypofractionated dose to the GTV and standard fraction doses to the CTVs [17]. Each strategy has pros and cons and no universally accepted schedule has been developed. The former solution may lead to the use of a very low $\mathrm{d}$./f. according to current standards; a daily d./f. below 1.6 Gy should be avoided. Notably, in one study, 58.1 Gy in 35 fractions were able to control the microscopic low-risk disease [18]. The latter approach has the disadvantage of using a higher d./f. (up to $2.5 \mathrm{~Gy}$ ) than the standard fractionation for the GTV potentially exposing normal tissues embedded within the high dose CTV to the risk of increased late toxicity. Moreover, this results in a higher than standard weekly total dose to normal tissues (i.e. mucosa) within the high dose region. According to some authors [19], 66 Gy/ $30 \mathrm{f}$. (2.2 Gy) should not be used in the context of concomitant CT. On the other hand, a d./f. up to $2.12 \mathrm{~Gy}$ is used in the context of concomitant CT (P, $100 \mathrm{mg} / \mathrm{m} 2 \mathrm{x}$ 3 cycles) for nasopharyngeal cancer [20]. Recently some authors have reported initial experience in advanced HNC with a d./f. up to 2.25 Gy in 30 fractions concomitantly to CT. This schedule seems feasible with an acceptable but not negligible acute toxicity rate, while a 
Table 1 Volumes at risk in HNC

\begin{tabular}{|c|c|c|c|c|c|c|c|c|c|c|c|c|}
\hline \multirow[t]{3}{*}{$\begin{array}{l}\text { Burden of } \\
\text { disease }\end{array}$} & \multirow[t]{3}{*}{ Description } & \multirow[t]{3}{*}{$\begin{array}{l}\text { ICRU } \\
\text { definition }\end{array}$} & \multirow[t]{3}{*}{$\begin{array}{l}\text { Adopted } \\
\text { definition }\end{array}$} & \multirow[t]{3}{*}{ Finality } & \multirow[t]{3}{*}{$\mathbf{T}$ - level } & \multirow[t]{3}{*}{$\mathrm{N}$ - level } & \multirow[t]{3}{*}{$\begin{array}{l}\text { Dose level } \\
\text { definition }\end{array}$} & \multirow{3}{*}{$\begin{array}{l}\text { Dose } \\
\text { level } \\
\text { NTD }\end{array}$} & \multicolumn{4}{|c|}{$\begin{array}{l}\text { Solution examples (Total-dose Gy/single-fraction } \\
\text { Gy/numbers of fractions }\end{array}$} \\
\hline & & & & & & & & & \multicolumn{2}{|c|}{ Definitive } & \multicolumn{2}{|c|}{ Postoperative } \\
\hline & & & & & & & & & Conventional & $\begin{array}{l}\text { Slightly } \\
\text { accelerated }\end{array}$ & Conventional & $\begin{array}{l}\text { Slightly } \\
\text { accelerated }\end{array}$ \\
\hline Macroscopic & $\begin{array}{l}\text { Known gross } \\
\text { disease }\end{array}$ & GTV & GTV & Definitive & Primary tumor & $\begin{array}{l}\text { Each Positive- } \\
\text { nodes }\end{array}$ & High Dose & 70 Gy & $70 / 2 / 35[18]$ & $\begin{array}{l}70 / 2.12 / 33 \\
{[20]}\end{array}$ & & \\
\hline \multirow[t]{6}{*}{$\begin{array}{l}\text { High risk of } \\
\text { microscopic } \\
\text { disease }\end{array}$} & $\begin{array}{l}\text { Risk of relapse }> \\
10-20 \%[54,55]\end{array}$ & CTV & $\mathrm{CTV}_{\mathrm{HD}} \wedge$ & Definitive & $\begin{array}{l}\text { Peri-GTV areas considered } \\
\text { to contain potential } \\
\text { microscopic disease } \\
{[38](T+10 \mathrm{~mm})^{*}}\end{array}$ & $\begin{array}{l}\text { Positive Nodes + } 5 \\
{[41]-10[53] \mathrm{mm}}\end{array}$ & & & & $\begin{array}{l}66 / 2.2 / 30 \\
{[17,18]}\end{array}$ & & \\
\hline & & & (CTV1) & & & & & & & $\begin{array}{l}65 / 2.17 / 30 \\
{[77]}\end{array}$ & & \\
\hline & & & & Post-S & $\begin{array}{l}\text { Surgical bed with soft } \\
\text { tissue involvement } \\
\text { (Positive or close margins): } \\
\text { PTB }+0.5-1 \mathrm{~cm} \text { according } \\
\text { to anatomical barriers [41]. }\end{array}$ & $\begin{array}{l}\text { Nodal region with } \\
\text { extracapsular } \\
\text { extension [41]: } \\
\text { PTB plus } 1 \mathrm{~cm} \text { up } \\
\text { to the skin [56]. }\end{array}$ & & $\begin{array}{l}66- \\
70 \text { Gy }\end{array}$ & & & $\begin{array}{l}\geq 63 / 1.8 / 35 \\
{[78]}\end{array}$ & $\begin{array}{l}65 / 2.17 / 30 \\
{[77]}\end{array}$ \\
\hline & & & & & & & & & & & & 66/2/33[79] \\
\hline & & & $\mathrm{CTV}_{\mathrm{HR}}$ & Definitive & $\begin{array}{l}\text { Preferential areas of } \\
\text { diffusion.(Optional) [56] }\end{array}$ & $\begin{array}{l}\text { Border-line lymph- } \\
\text { nodes }[51,57]\end{array}$ & $\begin{array}{l}\text { Intermediate } \\
\text { Dose }\end{array}$ & 60 Gy & $63 / 1.8 / 35[18]$ & $\begin{array}{l}60 / 2 / 30 \\
{[17,18]}\end{array}$ & & \\
\hline & & & (CTV2) & Post-S & $\begin{array}{l}\text { Surgical bed without soft } \\
\text { tissue involvement [41] }\end{array}$ & $\begin{array}{l}\text { Nodal region } \\
\text { without } \\
\text { extracapsular } \\
\text { extension }\end{array}$ & & $66 \S \mathrm{Gy}$ & & $\begin{array}{l}59.4 / 1.8 / 33 \\
{[20]}\end{array}$ & $\begin{array}{l}\geq 63 / 1.8 / 35 \\
{[78]}\end{array}$ & \\
\hline \multirow[t]{2}{*}{$\begin{array}{l}\text { Low risk of } \\
\text { microscopic } \\
\text { disease }\end{array}$} & $\begin{array}{l}\text { Risk of relapse } \\
5-10 \%[41,80]\end{array}$ & CTV & $C T V_{L R}$ & Definitive & $\begin{array}{l}\text { Structure or compartment } \\
\text { adjacent to tumor [56] }\end{array}$ & $\begin{array}{l}\text { Elective nodal } \\
\text { regions, defined } \\
\text { for each primary- } \\
\text { tumor subsite\# }\end{array}$ & Low dose & 50 Gy & $\begin{array}{l}58.1 / 1.66 / 35 \\
{[18]}\end{array}$ & $\begin{array}{l}54 / 1.8 / 30 \\
{[17,18,77]}\end{array}$ & & $54 / 2 / 27[79]$ \\
\hline & & & (CTV3) & Post-S & & & & $50 \mathrm{~Gy}$ & & $\begin{array}{l}50.4 / 1.8 / 28 \\
{[20]}\end{array}$ & $\begin{array}{l}57.6 / 1.8 / 32 \\
{[78]}\end{array}$ & $\begin{array}{l}54 / 1.8 / 30 \\
{[77]}\end{array}$ \\
\hline
\end{tabular}

*Depending from anatomic barrier; though one prospective study failed to show a benefit for 66 Gy over 60 Gy in the high risk post-operative region [78], this is the dose recommended by some cooperative groups (EORTC [79]); PTB: postoperative tumour bed; $\wedge$ definition of the high-risk region is controversial $[18] ; D=$ Definitive $R T ;$ Post- $S=$ postoperative. $C T V_{H D}: H i g h$ Disease; $C T V_{H R=}$ High Risk; $L R=L$ Low risk. ${ }^{C}$ in case of muscular infiltration (i.e. sternocleidomastoid muscle) at least the portion of the muscle surrounding the node [47] should be included. \# Similarly, it would be appropriate to include the whole muscle (i.e. sternocleidomastoid muscle) in CTV3/LR or when grossly infiltrated at some level. 


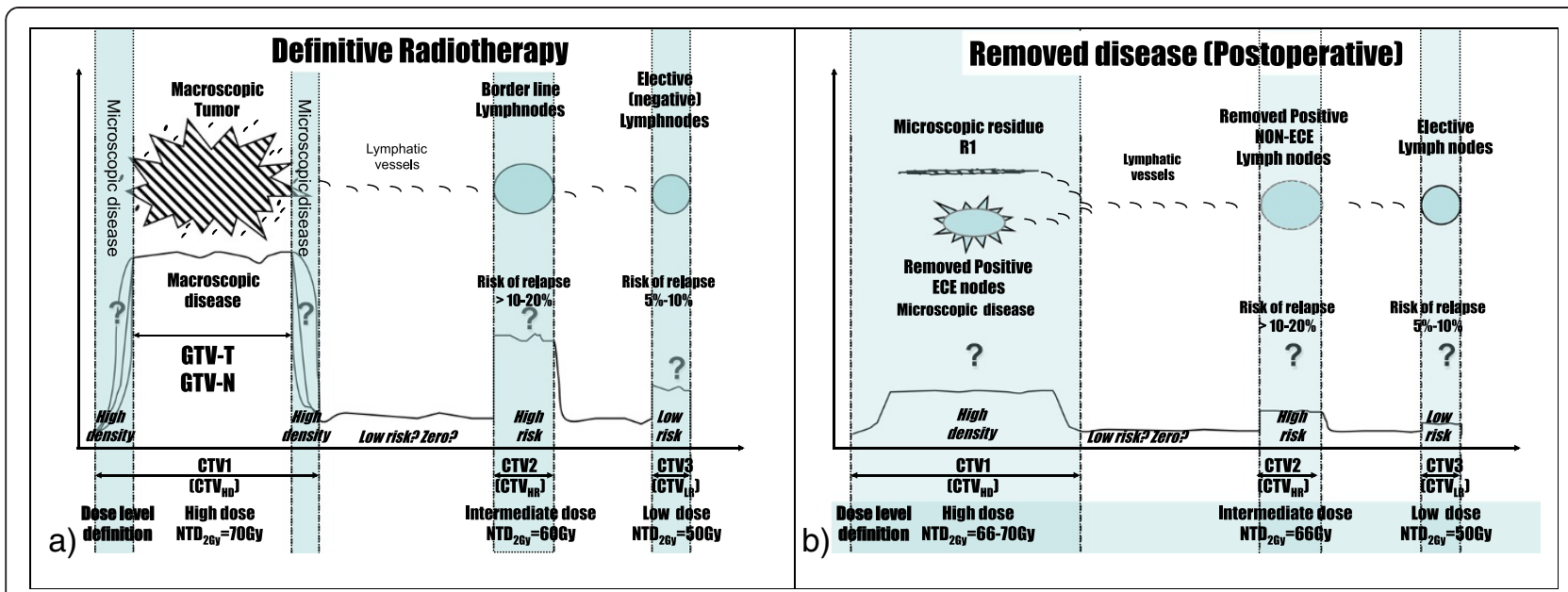

Figure 1 Volumes at risk in HNC (a) Definitive and b) postoperative RT). The Question mark "?" refers to the uncertainty of the tumour-cell density.

longer follow-up is needed to fully evaluate late effects $[21,22]$. In conclusion, hereinafter we will refer to IMRT as a SIB approach. The choice of the fractionation schedule (d./f.) is left to each Institution taking into account the aforementioned considerations. Whenever available, we will refer, for each primary site, to the fractionation schedules that have been tested clinically. We encourage each Institution to follow patients and investigate its own pattern of failure.

\section{Practical implications of induction/concomitant CT}

HNCs are typically treated once a day, i.e. 5 fractions per week ( $\mathrm{f} / \mathrm{w})$ (standard fractionation). Although a few studies, and one meta-analysis, have shown better locoregional control rates, and even improved survival, when multiple fractions per day are delivered [23-25], it is doubtful whether the treatment acceleration (more than $5 \mathrm{f} / \mathrm{w}$ ) is beneficial also in the context of concomitant CT. Two randomized studies [26,27] failed to show an advantage of concomitant chemo/accelerated-RT over standard CT/RT. Moreover, there are practical limitations in the number of treatment sessions that can be delivered per day with IMRT due to its workload intensiveness (each treatment session typically takes more than 15 minutes). RTOG [26] adopted a mildly accelerated radiation schedule $(6 \mathrm{f} / \mathrm{w})$ with concomitant $\mathrm{CT}$ as a standard, delivering the 6th fraction as a second daily dose on Friday (at least with a 6 hour gap) or on Saturday. In the context of concomitant CT there are no clinical data showing the benefit of multiple fractions per day (or more than $5 \mathrm{f} / \mathrm{w}$ ) or a single fraction per day higher than 2 Gy.

Regarding induction $\mathrm{CT}$, one potential advantage/pitfall is the potential downsizing of the primary tumour and lymph nodes. This can be successfully exploited in selected situations where the delivery of the highest dose level is limited by the tolerance of the surrounding normal structures (i.e. optic pathways for T4 NPC) [28]. On the other hand, it has been recommended that the initial rather than the post-chemo volume should encompass the high-dose region during contouring and planning [29]. With this in mind, the planning session should be carried out both before and after induction CT, if possible using the same immobilization device.

\section{Practical implications of upfront surgery}

Extensive surgery can disrupt normal anatomy and violate tissues that generally are not considered at risk of microscopic disease. In general, the whole operative bed is considered at some/low risk after surgery, with the initial site of disease at highest risk. This implies that, when a flap reconstruction is performed, the whole flap should be included at least in the lowest dose volume. Regarding the whole operative bed, doses in the order of 5054 Gy (2 Gy per fr) have been used [30,31]. It should be noted that the 'classical' recommendation is to include any surgically violated sites regardless of final pathology (i.e. the dissected neck that is found to be negative, pNo, should still be included in the lowest dose level) (Table 1). Regarding the initial site of disease, its identification is best based on pre-surgery imaging studies and operative notes. When incomplete resection is suspected, a repeated $\mathrm{PET} / \mathrm{CT}$ at $>1$ month after surgery has been shown to detect macroscopic residual disease in a significant proportion of patients [32]. Postoperative treatment should be started as soon as healing takes place (usually 2 weeks) and not later than 6-8 weeks after surgery [31]. Patients who fail after surgery may have a peculiar lymphnode-invasion pattern due to the distortion of normal lymphatic flow. Therefore, in this setting, lymph node involvement may be less predictable 
than in the previously untreated setting and hence deviate from the recommendations here provided.

\section{Pre-treatment evaluation}

The following procedures are recommended before starting RT:

1. Biopsy of the primary lesion. Fine needle aspiration (or more aggressive procedures) of suspicious lymph nodes may also be an option when the primary lesion is not evident (cTx) or when the presence of positive lymph nodes may have prognostic and/or therapeutic implications (i.e. definition of treatment volumes or the addition of $\mathrm{CT}$ ).

2. Panendoscopy under general anaesthesia with 'blind' tongue-base, tonsillar fossa, pyriform sinuses, Rosenmuller fossa biopsies or unilateral/bilateral tonsillectomy in unknown primary tumours.

3. Anamnesis (including tobacco and alcohol use, sexual habits, and current medications) and medical examination (including weight and performance status evaluation).

4. Indirect laryngoscopy and flexible endoscopic examination.

5. Complete dental evaluation (except for those receiving narrow fields for larynx cancer). Any required dental extractions must be perfomed and fluoride prophylaxis instituted prior to RT.

6. Speech pathology evaluation, including instrumental and/or clinical swallowing assessment and administration of pretreatment swallowing and trismus exercises, completion of pretreatment QoL questionnaires.

7. Nutritional evaluation.

8. Completion of the following laboratory studies: CBC (complete blood count), metabolic panel including: sodium, potassium, glucose, calcium, magnesium, BUN (blood urea nitrogen), serum creatinine, total protein, albumin, alkaline phosphatase, total bilirubin, AST, ALT, creatinine clearance, and thyroid function (TSH).

9. Completion of the following radiological studies:

9.1 Head-and-neck CT with $<3 \mathrm{~mm}$ contiguous slices (with contrast enhancement, unless contraindicated);

9.2 Whole body ${ }^{18}$ FDG-PET/CT scan for locally advanced disease and for unknown primary sites (integration of both high resolution contrastenhanced CT and dedicated PET acquisition through the head and neck region are strongly suggested; as an alternative, CT of the chest \pm abdomen, in particular for salivary gland tumours);

9.3 Head-and-neck MRI with gadolinium including T1- and T2-weighted sequences in at least 2 different planes (strongly suggested for tumours involving the tongue base, salivary glands and nasopharyngeal cancer).

10. Audiogram is recommended if the inner ear is to be irradiated at mean dose $\geq 40 \mathrm{~Gy}$.

11. Post-operative MRI/CT, pre and post-operative PET (optional);

12. Testing the tumour specimen for Human Papilloma Virus (HPV) is also strongly recommended via in-situ hybridization or, indirectly, via p16 IHC (Immunohistochemistry) for oropharyngeal cancer, WHO-Type 1 nasopharyngeal cancer, and unknown primary tumours [33]. Testing the tumour specimen for Epstein Barr Virus (EBV) is strongly recommended for both nasopharyngeal and unknown primary tumours.

\section{Simulation}

1. The patient is usually set up on the treatment table in supine position. The immobilization device is generally a thermoplastic mask immobilizing both head and shoulders [34]. A mouth piece is also indicated for all non-edentulous patients. A tongue depressor is generally not recommended except for tumours of the nasal cavity and paranasal sinuses (to move the tongue and the mouth floor away from the irradiated volume) or for tumours of the bottom of the oral cavity (to displace the upper part of the oral cavity). Dental prostheses have to be removed. The position of the head is usually neutral and comfortable except in selected situations detailed in each section. The patient is instructed to breath normally/quietly and not to swallow during scanning. Scars are usually wired. A 3-5 mm bolus over the larynx is also optional depending on the beam energy and the patient's thickness when the larynx is part of the target (especially for lesions involving the anterior commissure and beyond). A 3-5 $\mathrm{mm}$ bolus is also to be considered over areas of skin infiltration and/or after surgery in case of nodal extra-capsular extension (ECE).

2. Treatment planning CT scan should be performed having the patient in the treatment position. I.V. contrast liquid administration at the time of simulation is also recommended. MRI-scan planning is optional.

3. CT-scan thickness should be $0.3 \mathrm{~cm}$ or less through the region that contains the primary target volumes. The regions above and below the target volume may be scanned with slice thickness up to $0.5 \mathrm{~cm}$. MRI and PET/CT scans may be included to assist in defining target volumes as appropriate. 
4. The GTV, CTV and PTV and normal tissues are outlined on all the appropriate CT slices.

5. Patients should be trained to avoid swallowing in order to reduce organ motion during treatment.

\section{Volume and ICRU reference point definitions}

The definition of volumes is in accordance with ICRU Reports $n^{\circ} 50$ [35] and $n^{\circ} 83$ [36]:

1. The Gross Tumour Volume (GTV) is defined as all known gross disease determined by $\mathrm{CT}$, clinical information, endoscopic findings and MRI in case of tumours treated after biopsy alone. Functional information can be used to define sub-GTVs that are to receive some additional absorbed dose [37].

Typically, different GTVs are defined for the primary tumour (GTV-T) and the regional node(s) $($ GTV-N). Yet in those clinical situations in which the metastatic node cannot be distinguished from the primary tumour, a single GTV encompassing both the primary tumour and the node(s) may be contoured (GTV-TN) [38].

Furthermore, in consideration of adaptive RT, any changes occurring within the GTV during treatment can be quantified with anatomic- and/or functional-imaging techniques, allowing for the definition of a modified GTV in order to adjust the absorbed-dose distribution $[39,40]$.

Thus, because GTV contouring can vary according to the diagnostic modality used (e.g. clinical examination, anatomic and/or functional imaging) and the time/dose of acquisition with respect to the start of treatment (e.g. in the case of adaptive RT), a clear annotation is required. For example, ICRU 83 recommends specifying the imaging technique and pre-delivered dose: e.g. GTV-T (MRI-T2, 30 Gy), GTV-T (clin, 0 Gy).

2. The Clinical Target Volume (CTV) is contoured by the treating physician and is defined as a volume of tissue that contains a demonstrable GTV and/or subclinical malignant disease with a certain probability of occurrence considered relevant for therapy [38]. The notion of subclinical malignant disease includes the microscopic tumour spread at the boundary of the primary-tumour GTV, the possible regional infiltration into lymph nodes, and the potential metastatic involvement of other tissues. The selection of the tissues that bear risk for microscopic infiltration outside the GTV is a probabilistic assessment integrating the biological and clinical behaviour of the various tumour entities. Consideration may also be given to the presence of any specially radiosensitive normal tissue (Organs at Risk) as well as to other factors such as patient's general conditions [35].

2.1. Clinical experience indicates that in the region around GTV (Figure 1 a,b) there is generally subclinical involvement, i.e. individual malignant cells, small cell clusters, or microextensions, which cannot be detected through clinical staging procedures. The GTV together with this surrounding volume of local subclinical involvement can be defined as a clinical target volume (CTV-T for primary tumour, and CTV-N for metastatic lymphadenopaties, etc.). If the same dose is prescribed for two such CTVs and if they are close to each other, they can be labelled CTV-TN. This volume has to be considered for therapy and, if included, should be irradiated adequately to achieve cure. The margin between each GTV and its CTV should be typically 10-20 mm, with a minimum of $5 \mathrm{~mm}$ except in those areas where the GTV is immediately adjacent to structures known to be uninvolved (i.e. anatomic barriers). To account for the risk of extracapsular spread, a margin should also be added to the involved nodes [41].

2.2. Additional volumes (CTVs) with presumed subclinical spread (Figure 1a,b) (e.g. regional lymph nodes, N0) at a distance from a GTV also need to be considered for therapy [42]. In this situation the prescription is based on the assumption that in some anatomically definable tissues/organs, there may be cancer cells at a given probability level, even though they cannot be detected as they are subclinical. The level of probability is based on clinical experience from adequately documented treatments and follow-up. For the purpose of treatment prescription, it can usually be described in terms of frequency of risk for later detectable manifestations (failure rate), when untreated adequately in the subclinical setting [43]. There is no general consensus on which probability is considered relevant for therapy $[18,38,44]$, but typically a probability of occult disease higher than 5-10\% is assumed to require treatment. However, the volume could be defined as at "high-risk" (CTVHR or CTV2) or "low-risk" (CTVLR or CTV3) (Figure 1a/b) in consideration of the probability and entity of microscopic infiltration and could be targeted at different dose levels $[18,41,44]$.

Moreover, in HNC the probability of pathologic lymph-node involvement has been well described, and the distribution follows a predictable pattern allowing clinicians to tailor 
the CTV to the primary-tumour location and extent [18,45-47].

In postoperative cases, the CTV includes the operative bed and adequate margins according to an assessment of the risk of subclinical disease. The contouring of GTV and CTV are based on purely anatomic-topographic and biological considerations (morphology, such as ulcerative or exophytic, infiltrative or pushing front) with no regard to technical treatment factors [35,43]. Consequently, rather than simply expanding the GTV uniformly, it is recommended that the CTV should be contoured on a slice-by-slice basis [48]. Hereinafter, peri-GTV, CTVHR and CTVLR will be respectively defined CTV1 (e.g. CTV-T 1; CTV-N 1; CTV-TN 1), CTV2 and CTV3.

3. The Planning Target Volume (PTV) will provide a margin around each CTV to compensate for the uncertainties of treatment set-up and tissue deformation. An isotropic expansion of $5 \mathrm{~mm}$ is typically added around the CTV to define each respective PTV. For patients undergoing daily IGRT, the margins are sometimes cut down to $3 \mathrm{~mm}$, though this is controversial [49]. Margins can be further expanded in special situations (i.e. concerns on set-up error). Nevertheless, institution specific margins are strongly recommended.

4. In patients who receive neoadjuvant $\mathrm{CT}$, the postCT GTV will differ from what is seen on diagnostic images and the former should be outlined. The CTV, however, should be tailored to encompass the preCT GTV [29] (see Figure 2).

5. To facilitate planning a suffix indicating the prescribed dose to each CTV should be used, e.g. CTV70, CTV60, CTV50, etc.

6. Unless otherwise specified, here we will refer to the 3 definitive and 2 postoperative dose levels as reported in Table 1.

\section{Primary-tumour contouring (GTV-T): high dose volume (CTV-T 1)}

The GTV is usually defined based on physical examination and imaging findings. While the addition of MRI to CT contributes to improve tumour detection and observer consistency, the role of functional imaging to
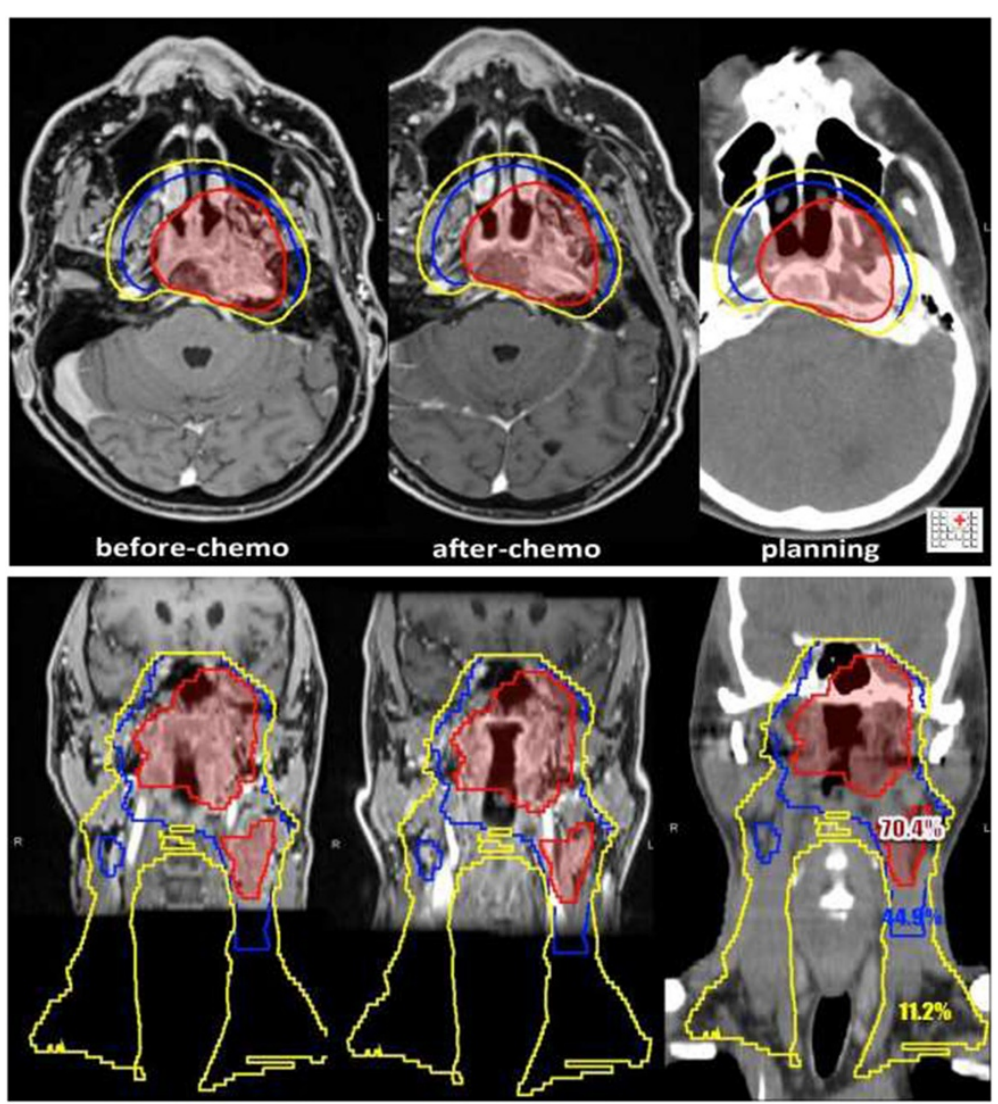

Figure 2 Nasopharynx. Countered volumes (before and after ChT). 
define the GTV is less established. Some authors disregard the information from FDG PET-CT [50].

Once identified, the GTV is usually expanded to its corresponding CTV (CTV1) by $0-10 \mathrm{~mm}$ depending on the presence of anatomic barriers, image quality and the presence of artefacts (dentures). With 3DCRT the whole portion of the sub-site, or a major part of it, is included in the CTV1 (e.g. the whole larynx and the whole rinopharynx in the case respectively of laryngeal and nasopharyngeal primaries). Conversely, with IMRT and according to ICRU directions, there is the tendency to limit the high dose region to the part of the sub-site, involved by disease.

Positive neck nodes (GTV-N): high dose volume (CTV-N 1) Lymph node stations or levels in the neck follow the surgical nomenclature. Cervical nodes are usually considered positive on contrast-enhanced CT scans if they show one or more of the following features: maximum axial diameter $>1 \mathrm{~cm}$ (5 $\mathrm{mm}$ if retropharyngeal); oval/ round as opposed to reniform shape; suspected focal necrotic hypodensity; irregular enhancement pattern; presence of extra-capsular penetration as judged by spiculated margins [51] and clusters of 3 or more borderline nodes [52]. A station is considered positive if it contains positive lymph nodes. For positive nodes, a 'full' radiation dose is usually recommended. However, in this case, only the positive lymph node(s) and not the whole station is (are) contoured as GTV. Moreover, expansion from GTV to CTV1 does not imply that the whole level would be part of CTV1. Some authors would add 5 [41]-10 [53] mm around the GTV of lymph nodes to account for potential subclinical (extracapsular) spread [41].

\section{Intermediate dose volume: high risk volume (CTV 2)}

Within a definitive treatment, the definition of the intermediate dose region is highly subjective, variable across Institutions [18] and considered optional. Ideally it would correspond to the regions at high risk of containing microscopic disease $(>10-20 \%[54,55])$, preferential regions of diffusion around the primary tumour [56] or lymph nodes that are borderline or suspicious. (i.e. between 7-9 $\mathrm{mm}$ in greatest axial dimension in neck levels III through IV; with a rounded appearance defined as a width to length ratio greater than 0.5 ; lack of fatty hilum or a cluster of three or more borderline nodes) [51,57]. The factors affecting this risk should be taken into account for each case: tumour stage, size, thickness $(3 \mathrm{~mm}$ or more is associated with a high metastatic risk for oral cavity tumours), differentiation, keratinization status, lymphatic vessel invasion in the tumour specimen, and whether other neck levels are involved [16].
Again, as for positive nodes, it is unclear whether the whole level at risk should be included within a given higher dose or only the suspicious node. We usually favour the latter, since in one study all neck failures originated from pre-treatment suspicious nodes [18].

\section{Elective neck contouring: low risk volume (CTV 3)}

There are several definitions available for neck nodal levels and here we will refer to the one used by cooperative groups (RTOG/EORTC). Accordingly, there are several papers and atlases that have reported guidelines for nodal level contouring both without and after surgery $[47,58,59]$. Compared to volumes treated with 3DCRT, current definitions of neck levels provide only partially overlapping volumes and the mismatch is particularly evident for some levels (i.e. levels IB and V) [59]. However, once identified, it is possible to irradiate precisely and selectively different node levels wit IMRT. Hereafter we will refer to the neck nodal levels ipsi- and contralateral to the primary site for each subsite.

Finally, it would be appropriate to include the whole muscle (i.e. sternocleidomastoid muscle) in CTV3/LR or when grossly infiltrated at some level.

\section{Organ at risk (OAR) \\ Definition}

Several OARs and tissues are routinely contoured on each patient planning $\mathrm{CT}$ as follows: mandible/TM joints, brain, brainstem, cord, parotid glands, upper gastrointestinal mucosa, larynx, oesophagus, brachial plexuses, inner ears, optic chiasm, optic nerves, ocular bulbs, lenses, major lacrimal glands, pituitary gland, submental connective tissue. For planning purposes, the cord and brainstem are usually expanded (by $5 \mathrm{~mm}$ ) as well as the optic pathway structures (optic chiasm, optic nerves and both retinas) to form a PRV (planning reference volume). PRV expansion, as PTV expansion, depends on set-up accuracy and set-up errors as well as on the IGRT technique.

Optional (that are usually not constrained) OARs include: submandibular glands, thyroid gland, masticatory spaces, upper, middle, and inferior constrictor muscles, crico-pharyngeal muscle, carotid arteries, lung apexes.

\section{OARs dose (volume) objectives}

Dose volume objectives are summarized in the Table 2.

Contouring indications and structured atlases [60,61] can be herein found:

- http:/groups.eortc.be/radio/res/gregoiratlas/ ln_levels_neck.pdf;

- http://www.rtog.org/LinkClick.aspx?fileticket = TjrmNiHXly8\%3d\&tabid $=229$. 
Table 2 Organs at risk

\begin{tabular}{|c|c|c|c|c|c|}
\hline OAR [81] & Priority & Endpoint & Goal & Minor variation & Comment \\
\hline Cord & PRIM & $0.1 \mathrm{cc}$ & Dmax $\leq 44-45$ Gy & Dmax 46 Gy & \\
\hline Cord (PRV) & PRIM & $0.1 \mathrm{cc}$ & Dmax 44-48 Gy & Dmax 48-50 Gy & \\
\hline Brain & PRIM & $1 \mathrm{cc}$ & Dmax 60 Gy & Dmax 63 Gy & \\
\hline Temporal lobes & PRIM & $1 \mathrm{cc}$ & Dmax 60 Gy & Dmax 65 Gy & \\
\hline Brainstem (PRV) & PRIM & $0.1 \mathrm{cc}$ & Dmax 54 Gy & Dmax 60 Gy & \\
\hline Chiasm (PRV) & PRIM & $0.1 \mathrm{cc}$ & Dmax 54 Gy & Dmax 60 Gy & \\
\hline Optic nerve (PRV) & PRIM & $0.1 \mathrm{cc}$ & Dmax 54 Gy & Dmax 60 Gy & \\
\hline Larynx & PRIM & $1 \mathrm{cc}$ & Dmax 73.5 Gy & Dmax 77 Gy & \\
\hline Mandible & PRIM & $1 \mathrm{cc}$ & Dmax 70-73.5 Gy & Dmax 75-77 Gy & \\
\hline Inner ear & SEC & D mean & $<50 \mathrm{~Gy}$ & $<52.5$ Gy & \\
\hline Larynx (without cartilaginous framework) & SEC & V50 & $<25 \%$ & $<30 \%$ & Oedema \\
\hline Larynx (supraglottis) & SEC & Dmax & $<66 \mathrm{~Gy}$ & & Dysphonia \\
\hline Larynx (whole organ) & SEC & Dmax & $<50 \mathrm{~Gy}$ & & Aspiration \\
\hline Mandible & SEC & V55 & $<20 \%$ & & \\
\hline Esophagus & SEC & $1 \mathrm{cc}$ & Dmax 45 Gy & Dmax 55 Gy & \\
\hline \multirow[t]{3}{*}{ Parotid gland } & SEC & V30 & $<50 \%$ & $<60 \%$ & at least one \\
\hline & SEC & Dmean & $\leq 26$ Gy & & at least one \\
\hline & SEC & V40 & $<33 \%$ (contralat) & & \\
\hline Upper Gl mucosa (outside PTV) & SEC & $1 \mathrm{cc}$ & $<30 \mathrm{~Gy}$ & $<36 \mathrm{~Gy}$ & \\
\hline Upper GI mucosa (whole volume) & SEC & V66.5 & Dmax 64 Gy (<3 \%?) & Dmax 70 Gy $(<5 \%)$ & \\
\hline Brachial plexus & PRIM & $0.1 \mathrm{cc}$ & Dmax 60 Gy & Dmax 66 Gy & SEC in selected \\
\hline Thyroid Gland & SEC & V45 & $<50 \%$ & & \\
\hline Submandibular gl & SEC & Dmean & $<35 \mathrm{~Gy}$ & & \\
\hline Constrictor pharyngeal mm & SEC & Dmean & $<50 \mathrm{~Gy}$ & & \\
\hline Lacrimal gland & PRIM & Dmean & $26 \mathrm{~Gy}$ & & SEC in selected cases \\
\hline Lens & PRIM & Dmax & $<4 \mathrm{~Gy}$ & $<6 \mathrm{~Gy}$ & SEC in selected cases \\
\hline Retina & PRIM & $0.1 \mathrm{cc}$ & Dmax 54 Gy & Dmax 60 Gy & \\
\hline Pituitary gland & SEC & Dmax & $<50 \mathrm{~Gy}$ & & \\
\hline TM joints & PRIM & $0.1 \mathrm{cc}$ & $<70 \mathrm{~Gy}$ & & \\
\hline
\end{tabular}

Dose and constraints reporting and recording should be standardized according to Institution guidelines.

The tolerance parameters reported here have only an indicative value since they may vary significantly among individual patients based on genetic factors, co-morbidities, concurrent or previous treatments, clinical status, habits and supportive treatments. Moreover, it should be noted that dose fractionation may influence the risk of both acute (weekly total dose) and late (d./f.) reactions. The doses reported below should to be considered equivalent to 2 Gy d./f.; their use at a lower d./f. would be conservative, or allow for extra safety.

\section{PTV dose (volume) objectives}

The process of developing a treatment plan consists of 3 components: (1) the definition and description of the "planning aims" and the desired absorbed-dose levels; (2) a complex beam delivery "optimization" process to achieve and, if needed, modify the initial "planning aims"; (3) a complete set of finally accepted values, which becomes the "prescription". When optimized, the absorbed-dose distribution is accepted by the physician.

In the Literature different parameters regarding PTV prescription and dose homogeneity are reported [62-64].

Hereinafter, the prescription dose is defined as the isodose encompassing at least $95 \%$ of the PTV.

Target dose restrictions include the followings: no more than $20 \%$ of any PTV could receive $>110 \%$ of its prescribed dose, no more than $1 \%$ of any PTV would receive $<93 \%$ of the prescribed dose, and no more than $1 \%$ or $1 \mathrm{cc}$ of the tissue outside the PTV would receive $>110 \%$ of the dose prescribed to the primary target [17]. 


\section{Planning issues}

- Split Field vs. Whole Field IMRT. Most Institutions would plan IMRT for HN cancers considering the whole volume ('whole field IMRT', WF-IMRT).

However, some Authors, especially in absence of positive lymph nodes and for tumours above the arytenoids (i.e. tonsil) propose the use of IMRT for the upper part of the volume keeping a low, anterior-posterior parallel-opposed beam approach to cover the lower neck and the supraclavicular nodes ('split field IMRT', SF-IMRT). The issue has been highly debated in the literature $[62,65]$. Although there are pro and cons for each strategy, our preference is to use WF-IMRT especially when nodes are present in the mid/low neck to avoid underdosing of the volume junction.

- Static IMRT vs. VMAT. IMRT takes several minutes to be delivered and this may be uncomfortable for the patient and workload intensive for the Institution (a typical time slot for treatment reaches 30 minutes including IGRT). Tomotherapy allows for the delivery of volumetric IMRT in a shorter period of time and sharper dose distributions with doubtful clinical impact [66]. Linac-based volumetric IMRT, VMAT or Rapid Arc, offers the advantage of less monitor units and shorter delivery times over static IMRT [67], but no clear advantage (and possibly disadvantage) in terms of target coverage and OAR sparing. Although this is a rapidly evolving field, the impression is that VMAT/RA may not offer the same dose distribution of IMRT/Tomotherapy for complicated cases [67]. Within this uncertainty, it seems reasonable to implement VMAT/RA, at least initially, in simple cases and with a dosimetric comparison to standard IMRT.

- Tissue deformation during treatment. Most patients undergoing RT $\pm \mathrm{CT}$ for HNC may lose a significant proportion of their weight (on averages 6\% to $12 \%$ of pre-treatment body weight [68]) during a 7-week course. Sometimes, large nodal masses show a dramatic shrinkage [69]; especially when adjacent to surrounding normal structures (cord, parotids), the dose distribution during treatment may deviate significantly during treatment compared to initial planning [70]. Finally, it has been shown that almost all OARs undergo significant changes during treatment, with about 30\% of shrinkage for major salivary glands, $10 \%$ for muscles (with the exception of constrictors) and 15\% increase for larynx and constrictors [71]. The cord, the brain and other nervous tissue structures seem unaffected. An adequate supportive/nutritional treatment (including enteral feeding) has proven to limit weight loss during treatment, increase patient compliance and ultimately patient's quality of life [72]. Which is the role of daily IGRT and adaptive re-planning in this setting is still undefined. Daily IGRT may reduce both systematic and random errors and thus may be preferable over weekly KV orthogonal films that address only the former [73], though no firm clinical data support this recommendation. One issue with the $\mathrm{HN}$ district is the relative motion of structures, i.e. the mandible and shoulders relatively to the neck and the deformability of structures (i.e. neck curvature). These limit the success of corrections using translations. Re-planning should be currently limited to cases where the changes in anatomy jeopardize the clinical outcome, i.e. increase in dose to the cord due to shrinking neck masses [70]. Fortunately, only a minority of cases $(<5 \%)$ show such modifications during treatment, and overall most patients still fail within the high dose region suggesting that geographic misses both at planning and during treatment are not a prevalent cause of failure. At present, rescanning of the patient during treatment (with subsequent recalculation of the dose distribution on the new planning $\mathrm{CT} \pm$ re-optimization) is considered at some Institutions mainly in patients with significant (>10\%) weight loss or (nodal) tumour changes.

- Dental artefacts and tissue heterogeneity calculation. Metal artefacts, in form of fixed intracavitary dental alloys, may induce dose alterations with dose enhancement that can lead to adverse tissue complications in OARs in contact to or near PTVs, and dose attenuation that may potentially spare cells within the target volume.

- Two methods have been proposed to limit tissue heterogeneity. A method that uses a model with four different material classes: air, soft tissue, bone, and metal. Pixels belonging to the same class are assigned to the same representative Hounsfield unit (HU). The HU of the pixels in the streaks resulting from the presence of metal are replaced as much as possible by the Hounsfield units of the soft tissue class or bone class [74], thus reducing artefact influence on dose calculation. Another method uses MV-CT imaging obtained with the treatment machine, with the patient in the treatment position, that can be registered with the simulation $\mathrm{kV}-\mathrm{CT}$ scan for the purposes of structure delineation, dose calculation, and treatment planning [75].

- Alternatively, a simple/basic empirical method is to override tissue density in the metal region after contouring. In this setting it is always prudent to rerun the dose calculation with the original tissue heterogeneity to better appreciate significant deviations. 
- PTV and skin. Whenever the tumour or clinical target volume approaches the surface of the skin, part of the PTV can extend into the build-up region of incident photon beams or even into the surrounding air (so-called in-air PTV). Most dose-computation algorithms cannot accurately compute absorbed dose in build-up regions. This will lead to a convergence error, i.e., the optimizer does not reach a global minimum for the objective function [76].

- Two solution are usually proposed: i. The PTVs are cropped so that they are restricted to $3 \mathrm{~mm}$ below the contoured body surface to prevent optimization issues in the build-up region except for areas where the skin is considered a part of the CTV. In the latter situation, a bolus is suggested, as stated in the "simulation" chapter. In addition, the PTV receiving lower dose is cropped from the overlapping higher dose PTV to facilitate optimization. After optimization, a skin flash region (virtual bolus) is used to obtain a sufficient fluence in surrounding air to cover the original PTV. ii. Planning-target-volumes are subdivided and a relaxation of the planning aims is used (ICRU 83).

- PTV overlapping OARs. The second solution proposed in previous situation is the preferred one when there is a PTV/PRV overlapping knowing that it is a trade-off between the coverage of the PTV with the aimed dose and the saving of OARs within the constraints.

\section{Oral cavity}

Cancers of the oral cavity are usually managed by upfront surgery and postoperative (chemo)RT. RT can be used as primary therapy for small (T1, T2) tumours of the oral cavity. Best results are with a combination of external beam radiation and brachytherapy.

IMRT is often used for oral cavity SCC to limit the dose to OARs and primarily to the parotid glands. However, compared to 3DCRT, it is associated with longer delivery or treatment session time. This may not be an ideal option for patients, who, especially after extensive surgeries, due to accumulation of secretions in the mouth, may not tolerate the supine position. Sometimes suctioning secretions before treatment delivery helps to maintain the treatment position during IMRT. Furthermore some initial reports with IMRT register marginal failure especially in patients with perineural invasion raising the question whether conventional opposed lateral fields might be a better option, also highlighting the importance of target delineation [82] [83].

\section{Dose/fractionation remarks}

Table 3 shows the commonly used fractionation regimens in the curative setting.

Table 4 shows the commonly used fractionation regimens in the post-operatve setting:

\section{Primary-tumour contour Definitive treatment}

1. Table 5 describes anatomical landmarks in contouring various oral subsites

2. At least a $1 \mathrm{~cm}$ margin around the GTV should always be added. In cases where the extent of the tumour is difficult to visualise it's preferable to use a $15 \mathrm{~mm}$ margins. CTV to PTV expansion also need to consider the local motility of the target (i.e. oral tongue) with respect also to the use of immobilization devices (i.e. tongue depressor) and their reproducibility. Anisotropic expansions (up to $10 \mathrm{~mm}$ ) are often used to accommodate regions at higher motility (i.e. the oral tongue).

\section{Postoperative treatments}

A positive margin on the oral tongue can be an indication for re-resection. Even when converted to negative, an initial positive margin carries a worse prognosis than an initially negative one [84] and thus should be considered at high risk of failure. In oral tongue cancers, perineural invasion (PNI) is an adverse feature that qualifies for adjuvant treatment at the primary site; moreover, in case of PNI, the value of a negative margin is somewhat questionable due to the possibility of a skip metastasis along the nerve route. In case of direct nerve invasion, e. g. if the inferior alveolar nerve is positive, the infratemporal fossa should be included in the radiation field because cancer can spread retrograde through the nerve into infratemporal fossa and to the skull base. The infratemporal fossa should also be included in the radiation field for tumour adjacent to this nerve with extensive perineural invasion and for tumour invading the pterygoid muscle, which is most commonly seen in patients with retromolar trigone cancers [82].

The CTV3 includes the whole operative bed and reconstruction site (i.e. free flap, mandibular reconstruction).

\section{Lymph-node station contour}

The neck (at least on the side of the disease) is often dissected during the removal of the primary tumour. As such, it is usually included in the lowest dose level regardless of pathology findings (just because part of the operative bed and thus potentially contaminated). A further dose is best judged based on the final pathology findings (high risk features, see above). Sometimes the clinically negative neck is not dissected (usually when 
Table 3 Suggested fractionation regimens for definitive treatment of oral cavity cancers

\begin{tabular}{lllllll}
\hline Author & & D (Gy) & d (Gy) & Fxs & OTT (wks) & Comment \\
\hline Daly et al., [83] & CTV1 & 66 & 2.2 & 30 & 6 & With concurrent CT [83] \\
Yao et al., [82] & & 20 & 1.8 & 35 & 3 & Sequential boost [82] \\
& CTV2 & 54 & 1.8 & 30 & 6 & [82] \\
Yao et al., [82] & CTV3 & 54 & 1.67 & 30 & 6 & [83] \\
Daly et al., [83] & & 50.1 & & &
\end{tabular}

the indication for RT is based on other findings that are already known at the time of surgery-i.e. contralateral to $\mathrm{cN}+$ ). When dissected, indications for adjuvant treatment include: $\mathrm{pN}>1$ (multiple pathologically involved nodes/multiple levels); single node with extracapsular extension; incomplete neck dissection (i.e. lack of level IV dissection in patients with pathologically positive level III); atypical node location (i.e. skip metastasis in level III) (see Table 1) for dose level definitions).

Treatment of the neck can be unilateral for well lateralized lesions (i.e. buccal mucosa), in absence of cN2-N3 ipsilateral neck nodes [85] (see Table 6).

Oral tongue primaries carry a higher risk of contralateral nodal disease than other oral cavity sites because of the rich bilateral lymphatic drainage [86], therefore the bilateral neck should be irradiated in all oral tongue cancer patients with involved ipsilateral nodes, especially in high grade tumours or advanced $\mathrm{T}$ stages [82].

1. Oral tongue drainage is to ipsilateral level Ib and level II, III and even level IV with an incidence of skip metastasis of 10-15\% [87]. An adequate elective neck dissection for oral tongue SCC includes levels Ib-IV. Five to ten percent of oral tongue cancers have bilateral lymph node metastases $[88,89]$.

2. For oral cavity SCC, the risk of positive nodes is strictly correlated with the depth of primary tumour invasion. Three to $9 \mathrm{~mm}$ tumours have a $44 \%$ risk of positive nodes and a $7 \%$ risk of local recurrence; $>9 \mathrm{~mm}$ thickness is associated with a $53 \%$ risk of subclinical nodes and $24 \%$ of local recurrence $[90,91]$.
3. The floor of mouth and tip of the tongue drain to levels $I a, \mathrm{Ib}$ and II. The incidence of bilateral lymph node involvement is relatively high because many lesions are near or cross the midline $[88,89]$.

4. Tumours of the buccal mucosa and hard palate not exceeding midline drain to ipsilateral level Ib.

5. For well-lateralized lesions (at least $1.5 \mathrm{~cm}$ from midline) only the ipsilateral neck should be considered for treatment, especially in absence of N2-N3 disease (except for oral tongue, see above).

6. In general, for $\mathrm{cN0}-1$, elective nodal stations include Ib-III with the exceptions of IIb (Table 6). The addition of level Ia is for lesions of the floor of mouth, oral tongue and lower gingiva. Adding level IV is for lesions of the oral tongue, especially if in the posterior $2 / 3$.

7. The likelyhood that an oral cavity cancer involving cervical lymph nodes of levels I to III would also involve level IV is generally stated as $7 \%$ to $17 \%$, and the corresponding rate for level $\mathrm{V}$ is 0 to $6 \%[92,93]$;

8. For $\mathrm{cN} 2-3$, elective irradiation of level $\mathrm{V}$ is advised; in case of extension to the tonsillar region, also retropharyngeal nodes should be included.

\section{Nasopharynx (NPX)}

Standard treatment of nasopharyngeal carcinoma is definitive $\mathrm{RT} \pm \mathrm{CT}$.

Target definition remarks (Table 7)

1. $\mathrm{CTV} 1=\mathrm{GTV}+$ a margin of $\geq 5 \mathrm{~mm}$ should be given circumferentially but can be $0-1 \mathrm{~mm}$ if anatomical barriers are present. CT and MRI should be used to

Table 4 Suggested fractionation regimens for postoperative setting of oral cavity cancers

\begin{tabular}{|c|c|c|c|c|c|c|}
\hline Authors & & D (Gy) & d (Gy) & fxs & OTT (wks) & Comment \\
\hline Daly et al., [83] & CTV2 & 66 & 2.2 & 30 & 6 & For positive margins or ECE \\
\hline \multirow[t]{4}{*}{ Yao et al., [82] } & & $64-66$ & 2 & $32-33$ & 6.5 & $\begin{array}{l}\text { Sequential boost for extracapsular extension, positive or close margins, } \\
\text { bone or soft-tissue involvement. }\end{array}$ \\
\hline & & 60 & 2 & 30 & 6 & \\
\hline & & 63 & 1.8 & 30 & 6 & \\
\hline & CTV3 & 54 & 1.8 & 30 & 6 & \\
\hline \multirow[t]{2}{*}{ Daly et al., [83] } & & 50.1 & 1.67 & 30 & 6 & \\
\hline & & 58.1 & 1.66 & 35 & 7 & \\
\hline
\end{tabular}

A surgery-to-RT interval of $<6$ weeks improves local-regional control. 
Table 5 Anatomical landmarks in contouring various oral subsites

\begin{tabular}{|c|c|c|c|c|c|c|}
\hline Sub-site & Cranial & Caudal & Anterior & Posterior & Lateral & Medial \\
\hline $\begin{array}{l}\text { Oral } \\
\text { tongue/ } \\
\text { Floor of } \\
\text { the Mouth } \\
\text { (FoM) }\end{array}$ & $\begin{array}{l}\text { Superior } \\
\text { aspect } \\
\text { tongue }\end{array}$ & $\begin{array}{l}\text { Hyoid } \\
\text { bone }\end{array}$ & Symphysis menti & $\begin{array}{l}\text { Anterior oropharyngeal } \\
\text { mucosa }\end{array}$ & $\begin{array}{l}\text { To mandible. Includes } \\
\text { ipsilateral parapharyngeal } \\
\text { space }\end{array}$ & $\begin{array}{l}\text { Ipsilateral tongue/FoM in well } \\
\text { lateralized tumours. } \\
\text { Contralateral mandible in } \\
\text { midline or advanced tumours }\end{array}$ \\
\hline $\begin{array}{l}\text { Buccal } \\
\text { mucosa }\end{array}$ & $\begin{array}{l}\text { Inferior } \\
\text { aspect } \\
\text { zygomatic } \\
\text { arch/hard } \\
\text { palate }\end{array}$ & $\begin{array}{l}\text { Hyoid } \\
\text { bone }\end{array}$ & Angle of mouth & $\begin{array}{l}\text { Oropharyngeal mucosa. } \\
\text { Infratemporal fossa should be } \\
\text { included in HNCPs with } \\
\text { involvement or proximity to } \\
\text { inferior alveolar nerve }\end{array}$ & To overlying skin & $\begin{array}{l}\text { Oropharyngeal mucosa. } \\
\text { Contralateral parapharyngeal } \\
\text { space spared }\end{array}$ \\
\hline $\begin{array}{l}\text { Retromolar } \\
\text { Trigone }\end{array}$ & $\begin{array}{l}\text { Superior } \\
\text { aspect soft } \\
\text { palate/hard } \\
\text { palate }\end{array}$ & $\begin{array}{l}\text { Hyoid } \\
\text { bone }\end{array}$ & $\begin{array}{l}\text { Junction of } \\
\text { posterior third and } \\
\text { anterior two thirds } \\
\text { of the tongue }\end{array}$ & Oropharyngealmucosa & $\begin{array}{l}\text { To mandible. } \\
\text { Includes ipsilateral } \\
\text { parapharyngeal space }\end{array}$ & $\begin{array}{l}\text { Oropharyngeal mucosa } \\
\text { Contralateral parapharyngeal } \\
\text { space spared }\end{array}$ \\
\hline Hard palate & $\begin{array}{l}\text { Superior } \\
\text { aspect of } \\
\text { hard palate } \\
+10 \mathrm{~mm}\end{array}$ & $\begin{array}{l}\text { Hyoid } \\
\text { bone }\end{array}$ & $\begin{array}{l}\text { 10-15 mm anterior } \\
\text { margin on GTV } \\
\text { into palate }\end{array}$ & $\begin{array}{l}\text { Anterior aspect oropharyngeal } \\
\text { mucosa }\end{array}$ & $\begin{array}{l}\text { To mandible / medial } \\
\text { pterygoid muscle on both } \\
\text { sides. Includes both } \\
\text { Parapharyngeal spaces. }\end{array}$ & $\begin{array}{l}\text { To mandible/medial pterygoid } \\
\text { muscle on both sides. } \\
\text { Includes both parapharyngeal } \\
\text { spaces. }\end{array}$ \\
\hline
\end{tabular}

identify the primary tumour location [20,94] (Figure 2). Indeed, the clivus and nerves are best seen on MRI.

2. CTV 2 = whole NPX (Table 7) should be included in high risk volume regardless $T$ site $[20,95,96]$. Indeed Sham observed that only $7 \%$ of patients had involvement of one subsite regardless of $\mathrm{T}$ site [95]. The most outer boundary of CTV2 should be at least $10 \mathrm{~mm}$ from the GTV.

\section{Pathology remarks}

Histological subtypes: the old WHO classification of nasopharyngeal carcinomas [98], yet widely used in literature, should be replaced by the new one [99] in order to avoid confounding factors:

WHO type 1 = keratinizing carcinoma

WHO type 2.1 = non keratinizing differentiated carcinoma

WHO type 2.2 = non keratinizing undifferentiated carcinoma (with lymphoepitelioma variants)

WHO type 3 = basaloid SCC (a rarity)

While subsite only is not a predictor of treatment outcome, histological subtypes are strongly variables by race and strongly influence prognosis: a) The asian population have a greater proportion of non keratinizing tumours, up to $90 \%$ [100], while white Caucasian race has a $60-70 \%$ rate of non keratinizing tumours [101,102]. WHO Type I, II differentiated, and II undifferentiated lesions have $41 \%, 56.1 \%$ and $68.5 \%$ 5-year survival rates, respectively [103].

b) Moreover WHO subtypes influence the risk of nodal and distant metastases: Type 1 and 2 have a $60 \%$ and $90 \%$ rate of nodal involvement respectively at diagnosis; Type 1 and 2 have 5-8\% and 30-40\% distant metastases rate respectively at diagnosis [104].

c) Of note, the same radiation dose is prescribed for all variants.

Dose/fractionation remarks

Table 8 shows the commonly used fractionation regimens:

\section{Primary-tumour contour}

- Anatomic considerations (see also Table 7).

1. NPX is usually divided into 3 subsites: a) posterosuperior wall: extends from the level of the junction of

Table 6 Guidelines for contouring neck levels [57]

\begin{tabular}{|c|c|c|c|}
\hline & cNo & Ipsilateral N+ & Comment \\
\hline Tongue & Bilateral I-IV & $\mathrm{V}$ if $\mathrm{N} 2-3$ & Excluding $\| \mathrm{b}$ \\
\hline Floor of mouth (well lateralized) & Bilateral I-III & $\mathrm{IV}$ and $\mathrm{V}$ if $\mathrm{N} 2-3$ & Excluding $\mathrm{ll} b$ \\
\hline Hard palate & Bilateral Ib, Ila, III, RP & Add bilateral la, IV, V if N2-3 & Excluding $\| \mathrm{b}$ \\
\hline Upper retromolar trigone & Bilateral Ib, Ila, III, RP, ipsilateral la & Add contralateral la, bilateral IV and V & Excluding $\| \mathrm{b}$ \\
\hline Lower retromolar trigone & |psilateral I, ||, ||| & Add ipsilateral IV, V & Excluding $\| \mathrm{b}$ \\
\hline Buccal mucosa & |psilateral |b, |la, ||| & Add ipsilateral la, bilateral IV and V & Excluding $\mathrm{Ilb}$ \\
\hline
\end{tabular}


Table 7 Standard anatomic limits of Nasopharynx

\begin{tabular}{ll}
\hline Anterior & Posterior fourth to third of the nasal cavity and maxillary sinuses (to ensure pterygopalatine fossae coverage) \\
Posterior & Anterior third of clivus (entire clivus if macroscopic infiltration), retrostyloid space \\
Lateral & Lateral parts styloid processes (parapharyngeal space) \\
Cranial & a. Skull base (foramen ovale and rotundum bilaterally must be included for all cases), \\
& b. Inferior half sphenoid sinus - anterior half clivus (entire clivus and top sphenoid sinus if macroscopic infiltration or in T4 cases). \\
& For lesions confined to the nasopharynx, the pituitary fossa can be excluded from the irradiated volume [97]. \\
C. The cavernous sinus should be included in high risk patients (T3, T4, bulky disease involving the roof of the nasopharynx) \\
Soft palate
\end{tabular}

hard and soft palates to the base of skull; b) lateral wall: including the Rosenmüller fossa; c) inferior wall: consists of the superior surface of the soft palate.

2. The pharyngobasilar fascia is a robust fibrous aponeurosis situated between the mucous and muscular layers and covers the pharyngeal constrictor muscles; it is bound inferiorly by the superior pharyngeal constrictor, superiorly by the base skull, and anteriorly by the posterior border of the medial pterygoid laminae; it serves to attach the superior pharyngeal constrictor muscle to the base of the skull at both the basal part of the occipital bone and the petrous portion of the temporal bone; the Eustachian tubae generate an escape route for the tumour that frequently exceeds this aponeurosis and reaches the parapharyngeal and masticatory space.

- Neoplastic-behaviour considerations

1. Nasopharyngeal neoplasms typically arise near the Rosenmuller fossa.

2. The natural local growth follow four directions $[107,108]$ and this should be taken into account for CTV contouring:

a. Anterior:

i. nasal cavity;

ii. masticatory space via pterigomaxillary fissure; iii. carotid canal via anterior foramen lacerous;

iv. intracranial (medial cranial fossa) via foramen rotundum;

v. orbital cavity and cranial anterior fossa via superior orbitae fissure.

b. Lateral:

i. masticatory space via Eustachian tubae,

ii. posterior cranial fossa via giugular foramen and giugular internal vein;

iii. cavernous sinus via mandibular nerve and foramen ovale.

c. Posterior : prevertebral muscles and vertebrae via prevertebral fascia;

d. Inferior: oropharynx

- Therapeutic considerations

1. Induction $\mathrm{CT}$ is sometimes used for neoadjuvant purposes to shrink and downsize the tumour especially when it is abutting OARs whose tolerance is inferior to the prescribed GTV dose (i.e. brainstem). In this case, the pre-induction target should receive full dose $[29,109]$ (Figure 2), but the dose to the original site of disease is often limited to

Table 8 Suggested fractionation regimens for NPX

\begin{tabular}{|c|c|c|c|c|c|c|}
\hline Author & & D (Gy) & d (Gy) & fxs & OTT (wks) & Comment \\
\hline & CTV1 & 70 & 2 & 35 & 7 & \\
\hline N. Lee et al., 2009 & & 69.96 & 2.12 & 33 & 6.5 & RTOG0225 [20] \\
\hline K. Kim et al., 2009 & & 67.5 & 2.25 & 30 & 6 & [105] \\
\hline \multirow[t]{2}{*}{ Peponi et al., 2010} & & $66-69.63$ & $2.2-2.11$ & $30-33$ & & [106] \\
\hline & CTV2 & 63 & 1.8 & 35 & 7 & \\
\hline N. Lee et al., 2009 & & 59.4 & 1.8 & 33 & 6.5 & RTOG0225 [20] \\
\hline \multirow[t]{3}{*}{ K. Kim et al., 2009} & & $54-60$ & $1.8-2$ & 30 & 6 & [105] \\
\hline & CTV3 & 58.1 & 1.66 & 35 & 7 & \\
\hline & & 56.1 & 1.7 & 33 & 6.5 & \\
\hline N. Lee et al., 2009 & & 50.4 & 1.8 & 28 & & RTOG0225 [20] \\
\hline K. Kim et al., 2009 & & 48 & 1.6 & 30 & 6 & [105] \\
\hline Peponi et al., 2010 & & 51 & 1.7 & 30 & & [106] \\
\hline
\end{tabular}


the tolerance of surrounding OAR (i.e. $60 \mathrm{~Gy}$, optic pathways) while the residual tumour is prescribed/ delivered a full dose.

The patient should be simulated supine with the head hyperextended [110] to provide adequate separation between the primary lesion/retropharyngeal lymph node and the upper neck field and to avert eyes from the primary volume, or in neutral position.

\section{Lymphnode-level contour}

- Anatomic considerations.

There are three distinct pathways of lymphatic drainage from the nasopharynx: i. Postero-inferiorly to the retropharyngeal nodes (including the node of Rouviere); ii. Directly to superior deep cervical nodes; iii. Laterally to mastoid and spinal accessory nodes (level V).

The initial lymphatics (including capillary network and precollectors) arise in the wall of the nasal fossae and the nasopharynx.

The lymphatic collectors run into the parapharyngeal space to the lateral pharyngeal and retropharyngeal lymph nodes. They run through the lateral wall of the nasopharynx and form two lymph collectors (lateral and medial) that descend laterally to the pharyngeal wall in the parapharyngeal fat tissue:

i. the lateral one is situated on the lateral side of the external carotid artery;

ii. the medial is located one medially along the external carotid artery.

The lateral group provides lymphatic drainage from the lateral walls (including Rosenmuller Fossa) directly into deep nodes of the posterior triangle (upper level V) while the medial trunk drains to the superior deep cervical nodes (levels II and III) [111,112].

- Neoplastic-behaviour considerations

1. The primary lymphatic drainage of nasopharyngeal carcinoma is to retropharyngeal, II and Va nodal levels. Setting the cranial border of level IIb node at the skull base should be considered when delineating nodal target volume [113].

2. The secondary lymphatic drainage is to levels III and $\mathrm{Vb}$ [114].

3. Level IV is involved in $10 \%$ of the cases [115].

4. Level Ib is rarely involved; it has to be included only in case of clinical adenopathy evidence [115]. It should be noted, however, that the posterior part of level Ib was routinely irradiated in the old days [59].

5. Lymphatic drainage is bilateral. Therefore, both sides of the neck are at risk [41] (Table 9).

6. Retropharyngeal nodes (top of $\mathrm{C} 1$ to bottom of C2, sometimes C3 $[108,116])$ should be always included in the CTV2.

Few studies have investigated the option to withhold elective treatment for $\mathrm{cN} 0$ patients. One of them found a high regional salvage rate with either surgery or RT [117]. It should be noted, however, that patients with residual persistent disease in the neck or who fail in the neck have a higher risk of distant metastases than patients who do not fail in the neck. Therefore, comprehensive neck irradiation (including levels II-V) is always advocated for NP.

\section{Oropharynx}

The oropharynx is usually divided into 4 sub-sites: tonsil, base of tongue, pharyngeal walls and soft palate. While sub-site only is not a predictor of treatment outcome, HPV related tumours, with a more favourable prognosis compared to their alcohol and tobacco counterparts, usually originate from the base of tongue or tonsils. Currently there are no practical implications or differences between HPV positive and negative tumours.

\section{Dose/fractionation remarks}

Table 10 shows the common fractionation regimen.

\section{Primary-tumour contour}

- Historical perspective:

1. In the standard 3-field era, the whole oropharynx was included in the low dose region and the primary tumour boosted to the final dose. Whether the whole oropharynx should be included in the low risk region is somewhat controversial and no definitive recommendations can be made. However, some Authors, especially in presence of HPV related tumours (that seem to have a lower risk of field cancerization) tend to limit the low risk volume (CTV3) to the sub-site involved or, at most, the adjacent one (i.e. in

Table 9 Guidelines for contouring bilateral neck levels (negative on imaging)

\begin{tabular}{llll}
\hline Side & Level & Risk & Remarks \\
\hline Bilateral & $\begin{array}{l}\text { Retropharyngeal, } \\
\text { II, III, Va } \\
\text { IV, Vb }\end{array}$ & High & \\
IB & Low & $\begin{array}{l}\text { Higher risk when level III is } \\
\text { clinically involved } \\
\text { Omit or include only in } \\
\text { case of neck node positivity }\end{array}$ \\
\hline
\end{tabular}


Table 10 Suggested fractionation regimen for oropharyngeal cancer

\begin{tabular}{|c|c|c|c|c|c|c|}
\hline \multirow[t]{2}{*}{ Authors } & & D (Gy) & d (Gy) & Fxs & OTT (wks) & Comment \\
\hline & CTV1 & 70 & 2 & 35 & 7 & \\
\hline Eisbruch [17] & & 66 & 2.2 & 30 & 6 & T1-2 in absence of conc chemo (RTOG 00-22) \\
\hline \multirow[t]{2}{*}{ Sanghera [118] } & & 55 & 2.75 & 20 & 4.5 & Retrospective analysis \\
\hline & CTV2 & 63 & 1.8 & 30 & 6 & \\
\hline \multirow[t]{2}{*}{ Eisbruch [17] } & & 60 & 2 & 30 & 6 & T1-2 in absence of conc chemo (RTOG 00-22) \\
\hline & CTV3 & 58.1 & 1.66 & 35 & 7 & \\
\hline Eisbruch [17] & & 54 & 1.8 & 30 & 6 & T1-2 in absence of conc chemo (RTOG 00-22) \\
\hline Sanghera [118] & & 41.25 & 2.75 & 15 & 3 & \\
\hline
\end{tabular}

case of a tonsillar tumour, CTV3 would include the involved tonsil and the tongue base but not the contralateral tonsil).

2. In the old days, a typical initial field for a tonsillar tumour included the whole pterygoid plates up to the base of skull; therefore it is recommended that CTV3 cover the whole pterygoids as well.

- Clinical and anatomical considerations

1. Trismus is a surrogate of medial pterygoid muscle invasion and in this case a generous margin along with the medial pterygoid muscle should be contoured during CTV1 definition;

2. The anterior extent of the GTV in the tongue base is best evaluated via contrasted CT or even better with MRI; due to subclinical anterior extension, especially for infiltrative primary tongue base tumours, a generous margin $(1.5-2 \mathrm{~cm})$ around both CTV1 and CTV3 should be added anteriorly;

3. Patients with dentures that are likely to create visual artefacts should be positioned with the head in a different position (more flexed or extended); moreover, the location of the primary tumour should be driven by a different study, i.e. MRI;

4. After primary tumour (surgical) removal, unless the original location of the primary is clearly available and visible on a dedicated study, the whole sub-site should be part of CTV;

5. Parapharyngeal space is a locus minoris resistentiae and needs to be included in the CTV in the case of possible/suspected local extension and/or retro/ parapharyngeal node involvement (Figure 3).

\section{Lymphnode-level contour}

1. The primary lymphatic drainage of oropharyngeal SCC is to levels II, III and retropharyngeal nodes. Bilateral spread is fairly common for lesions that approach midline (such as in the case of the tongue base and soft palate), while it is relatively rare for well lateralized lesions (at least $1.5 \mathrm{~cm}$ from midline as in the case of tonsil primaries) in absence of multiple or large $(>3 \mathrm{~cm})$ lymph nodes; in addition, lesions arising or involving the soft palate have an increased risk of level I (Ib) involvement;

2. When the primary tumour is well lateralized (e.g. tonsil) and the ipsilateral neck shows limited involvement (N0-1, questionable N2a), contralateral neck coverage can be omitted;

3. Some Authors [59,119] would limit level IB coverage to its most posterior part. The anterior extent of the contour of level IB when included in CTV3 would stop at the anterior extent of the submandibular gland and, therefore, exclude the triangular fat space lateral to the deep extrinsic muscles of the tongue.

4. Retropharyngeal nodes (top of $\mathrm{C} 1$ to bottom of $\mathrm{C} 2$, sometimes C3) should be always included in the CTV3 unless suspicious ( $>5 \mathrm{~mm}$ ).

5. In case of suspicious neck nodes (as previously defined) and lymph node enlargement in other sites than ipsilateral levels II and III, the suspicious finding and not the whole level should be contoured as CTV2.

6. Table 11 provides some indications for contouring ipsilateral and contralateral neck levels that are negative at imaging.

\section{Hypopharynx}

SCC of the hypopharynx is usually diagnosed at a later/advanced stage. Moreover, due to local (submucosal) invasion, it is usually considered more aggressive/less radioresponsive than its laryngeal counterpart. Concomitant CT is usually indicated for T3-4 or any $\mathrm{T}+\mathrm{N}+$ [120-123], but some Authors in monoinstitutional experience [124,125] claim the use of concomitant CT also for earlier T stage (T2) lesions even if the only two large randomized trials specifically addressing the hypopharyngeal cancer subset [126,127] with few T2 patients included, used sequential or alternate ChT and RT and not concomitant treatments. In patient unfit for standard concomitant CT, induction CT or the concomitant association with Erbitux can be considered [11]. 


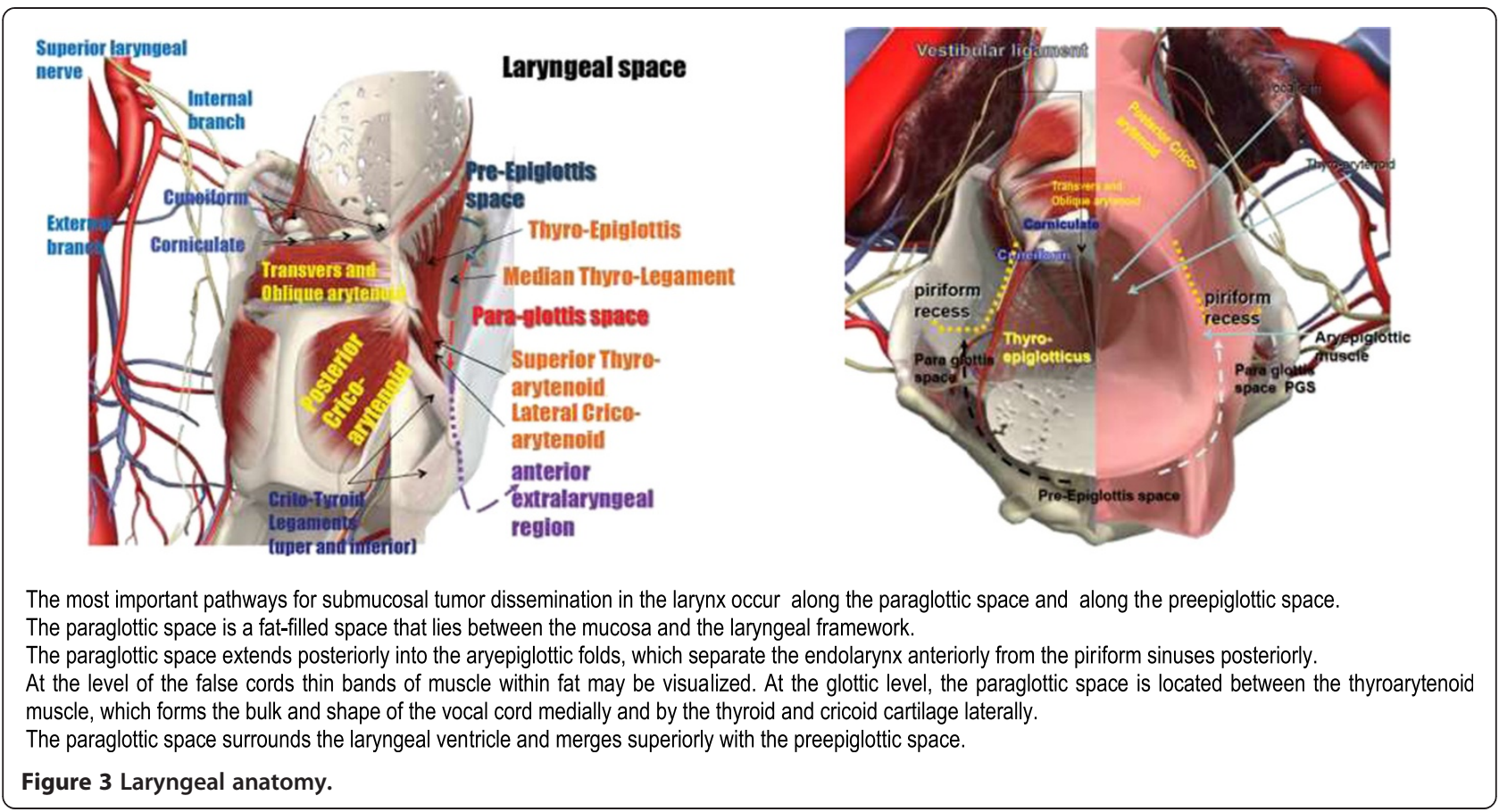

Due to concerns regarding treatment-related late toxicities, hypofracionation delivered with SIB is not recommended [122,128].

\section{Target definition remarks}

CTV2. After surgery, CTV2 would include the whole laryngo-pharynx bed with particular attention to the cranial and caudal extent of resection (i.e. cervical

Table 11 guidelines for contouring ipsilateral and contralateral neck levels negative at imaging

\begin{tabular}{|c|c|c|c|c|}
\hline Side & Level & Risk & & Remarks \\
\hline \multirow[t]{4}{*}{ Ipsilateral } & $\mathrm{lb}$ & Low & CTV3 & $\begin{array}{l}\text { Higher risk for soft palate/oral } \\
\text { cavity involvement or multiple } \\
\text { positive neck levels-CTV2 }\end{array}$ \\
\hline & $\|-|\||$ & High & CTV2 & $\begin{array}{l}\text { Lower risk when the whole } \\
\text { neck is negative (cNO)-CTV3 }\end{array}$ \\
\hline & IV & Low & CTV3 & $\begin{array}{l}\text { Higher risk when level III is } \\
\text { clinically involved- CTV2 }\end{array}$ \\
\hline & V & $\begin{array}{l}\text { Very } \\
\text { low }\end{array}$ & $\begin{array}{l}\text { CTV3 or } \\
\text { omit }\end{array}$ & \\
\hline \multirow[t]{4}{*}{ Contralateral } & IB & $\begin{array}{l}\text { Very } \\
\text { low }\end{array}$ & Omit & $\begin{array}{l}\text { Higher if the contralateral II-III } \\
\text { lymph node level is clinically } \\
\text { positive or the soft palate } \\
\text { is involved }\end{array}$ \\
\hline & $\|-|\||$ & Low & CTV3 & $\begin{array}{l}\text { Higher risk if the contralateral } \\
\text { level IB is clinically positive }\end{array}$ \\
\hline & IV & Low & CTV3 & $\begin{array}{l}\text { Higher risk when level III is } \\
\text { clinically involved }\end{array}$ \\
\hline & V & $\begin{array}{l}\text { Very } \\
\text { low }\end{array}$ & Omit & $\begin{array}{l}\text { Omit unless suspicious nodes } \\
\text { are found }\end{array}$ \\
\hline
\end{tabular}

oesophagus) and the site of dissected positive lymph nodes;

\section{Dose/fractionation remarks \\ Primary-tumour contour}

- Historical perspective:

- In the old days, the lower extent of tumour coverage (cricoid cartilage) needed a low neck junction that was particularly troublesome in patients with a short neck; nowadays with IMRT, the issue about adequate coverage of the caudal part of the CTV is overcome [128].

- Clinical and anatomical considerations

- The hypopharynx consists of the pyriform sinuses, postcricoid region and posterior pharyngeal wall. The anatomic boundaries of the hypopharynx include the ariepiglottic folds (superiorly), the cricoid cartilage (inferiorly), the prevertebral fascia (posteriorly) and the larynx (anteriorly).

- Unlike the larynx, the hypopharynx has no clear barriers to cancer extension. The boundary between the oropharynx and hypopharynx is theoretical and the boundaries between different subregions are more anatomical landmarks that real barriers.

- Because submucosal extensions are hardly visible, it is preferable to have larger volumes to reduce the risk of recurrence. Therefore, CTV2 would encompass $1-1.5 \mathrm{~cm}$ of normal mucosa cranial and caudal to CTV1 [129]. 
- The lower extent of the tumour is best evaluated with a dedicated esophagoscopy.

- Especially for lesions involving the medial wall of the pyriform sinus, the posterior part of the larynx (arytenoids and interarytenoid region) should be part of the CTV1 as well.

- Involvement and violation of the prevertebral fascia can be appreciated clinically (tumour fixation) and on imaging (MRI); in case of prevertebral space invasion, the lesion becomes unresectable and the margins for cranio-caudal microscopic tumor spread would be wider than usual.

- Indications to boost the stomal region after major surgery basically duplicate those for laryngeal primaries.

\section{Lymphnode-level contour}

1. Tumours of the hypopharynx have a high tendency to spread to lymph nodes.

2. The risk of subclinical disease in lymph nodes is not strictly correlated to the stage of the primary tumour.

3. Stations at risk are reported in Table $13[57,130]$.

4. Lymph node level VI has to be encompassed if oesophageal extension is present.

5. Ipsilateral retrostyloid lymph nodes should be included if clinical or radiological level II involvement is present.

\section{Larynx}

\section{Dose/fractionation remarks}

Table 12 reports the most used fractionation schemes for laryngeal cancer. The standard dose for T1N0 of the glottic larynx is 66 Gy /33 fxs/6.5 weeks. For T1 glottic lesions, the d./f. used within 3DCRT has been up to 3.43 Gy [131] (Total dose 55Gy/16 fractions); there is limited experience with IMRT for this fractionation, and

Table 13 Guidelines for contouring neck levels when negative at imaging in hypopharyngeal cancer

\begin{tabular}{|c|c|c|c|}
\hline Site & $\begin{array}{l}\mathrm{N} \\
\text { stage }\end{array}$ & $\begin{array}{l}\text { Levels to be } \\
\text { included }\end{array}$ & Remarks \\
\hline $\begin{array}{l}\text { Pyriform } \\
\text { sinus }\end{array}$ & No & Ila-IV bilateral & $\begin{array}{l}\mathrm{V} \text { and RP bilateral, } \mathrm{VI} \text { ipsilateral } \\
\text { if oesophageal extension }\end{array}$ \\
\hline $\begin{array}{l}\text { Pyriform } \\
\text { sinus }\end{array}$ & $\mathrm{N}+$ & $\begin{array}{l}\text { Ila-V-RP bilateral, } \\
\text { VI ipsilateral }\end{array}$ & $\begin{array}{l}\text { Ipsilateral retrostyloid lymph } \\
\text { nodes need to be included if } \\
\text { clinical or radiological level II } \\
\text { involvement is present. }\end{array}$ \\
\hline $\begin{array}{l}\text { Pharyngeal } \\
\text { wall }\end{array}$ & NO & $\begin{array}{l}\text { Ila-IV-RP bilateral, } \\
\text { VI ipsilateral }\end{array}$ & $\begin{array}{l}V \text { bilateral if esophageal } \\
\text { extention }\end{array}$ \\
\hline $\begin{array}{l}\text { Pharyngeal } \\
\text { wall }\end{array}$ & $\mathrm{N}+$ & $\begin{array}{l}\text { I-V, RP bilateral, } \\
\text { VI ipsilateral }\end{array}$ & $\begin{array}{l}\text { Ipsilateral retrostyloid lymph } \\
\text { nodes need to be included if } \\
\text { clinical or radiological level ॥ } \\
\text { involvement is present. }\end{array}$ \\
\hline
\end{tabular}

Table 12 Suggested fractionation regimens for hypopharyngeal and laryngeal cancer

\begin{tabular}{|c|c|c|c|c|c|c|}
\hline Author & & $\begin{array}{l}\text { D } \\
\text { (Gy) }\end{array}$ & $\begin{array}{l}\text { d } \\
\text { (Gy) }\end{array}$ & Fxs & $\begin{array}{l}\text { OTT } \\
\text { (wks) }\end{array}$ & Comment \\
\hline & CTV1 & 70 & 2 & 35 & 7 & \\
\hline Lee et al. [122] & & 70 & 2.0 & 35 & 7 & $\begin{array}{l}\text { 2-years PEG } \\
\text { dependent: 15\% }\end{array}$ \\
\hline $\begin{array}{l}\text { Studer et al. } \\
\text { [121] }\end{array}$ & & 69.6 & 2.11 & 33 & 6.5 & \\
\hline \multirow[t]{3}{*}{ Miah et al. [123] } & & 63 & 2.25 & 28 & 5.6 & Arm 1 (DL1) \\
\hline & & 67.2 & 2.4 & 28 & 5.6 & Arm 2 (DL2) \\
\hline & CTV2 & 63 & 1.8 & 35 & 7 & \\
\hline \multirow[t]{2}{*}{ Lee et al. [122] } & & 59.5 & 1.7 & 35 & 7 & \\
\hline & CTV3 & 58.1 & 1.66 & 35 & 7 & \\
\hline Lee et al. [122] & & 56.0 & 1.6 & 35 & 6.5 & \\
\hline $\begin{array}{l}\text { Studer et al. } \\
\text { [121] }\end{array}$ & & 54 & 1.64 & 33 & 6.5 & \\
\hline \multirow[t]{2}{*}{ Miah et al. [123] } & & 51.8 & 1.85 & 28 & 5.5 & \multirow{2}{*}{$\begin{array}{l}\text { Acute Grade } 3 \text { (G3) } \\
\text { dysphagia was higher } \\
\text { in DL2 ( } 87 \% \text { DL2 vs. } \\
59 \% \text { DL1) }\end{array}$} \\
\hline & & 56 & 2 & 28 & 5.5 & \\
\hline
\end{tabular}

thus the recommendation is to limit the d./f. to $2.25 \mathrm{~Gy}$ to 56.25-63 Gy [132] in the context of IMRT. For T2 glottic lesions, RTOG 9512 found only trend in favour of hyperfractionation over standard fractionation [133].

For more advanced lesions (T3-4) of the larynx, there are consolidated data on the benefit of altered fractionation in terms of both local control and survival; the best outcome is reached with hyperfractionation [134]. However, hyperfractionation hardly fits into an IMRT technique for reasons that have been previously discussed; moreover with the advent of ChT, RT alone is rarely used for T3-4 lesions.

In the postoperative setting, the most used schedule is: 66 Gy in 33 fractions (2 Gy daily) to CTV1, 59.4 Gy in 33 fractions (1.8 Gy daily) to CTV2 (optional) and $54,12 / 56,1$ in 33 fractions (1.64-1.7 Gy daily) to CTV3.

After subtotal laryngectomies (horizontal supraglottic laryngectomy-HSL, near total laryngectomy, hemilaryngectomy) there is the concern that adjuvant $\mathrm{RT}( \pm \mathrm{ChT})$ may jeopardize the functional outcome of the residual or surgically spared larynx [135]. For example, after HSL (horizontal supraglottic laryngectomy), it has been found that 60 Gy radiation significantly increases the risk of laryngeal edema (over 50 Gy) [136]. Therefore, unless specifically indicated (positive resection margins) and after careful discussion with the patient, the dose to the larynx should be kept within 50 Gy (see also below) $[137,138]$.

\section{Primary-tumour contour}

The larynx is divided into three anatomic regions: Supraglottis - suprahyoid epiglottis, infrahyoid epiglottis, 
aryepiglottic folds (laryngeal aspect), arytenoids, and ventricular bands (false cords). Glottis - true vocal cords, including anterior and posterior commissures. Subglottis subglottis, extending from lower boundary of the glottis to the lower margin of the cricoid cartilage [139].

\section{Definitive treatments}

\section{- Anatomical considerations}

1. Target volumes are defined according to the pathways of cancer extension in the larynx (Figure 3). Cancer of the larynx mainly spreads by direct extension (following the line of least resistance), prior to lymphatic spread and more rarely follows the vascular and neurological routes. The main way of diffusion of laryngeal cancer is to para-glottic and to the pre-epiglottic spaces through the anterior commissure, the thyro-epiglottic and thyro-arytenoid ligaments (upper and lower), the ligament and crico-thyroid membrane, the perforations of the sub-hyoid epiglottis, the bottom of the ventricle and laterally through the thyroid cartilage. These two spaces also play an important role for the $T$ classification, as neoplastic invasion of these spaces upstages laryngeal cancer to T3.

Therefore, if these structures are directly encompassed by GTV, CTV1 should include also pre-epiglottic and para-glottic space.

\section{- Historical perspective}

1. In the 3DCRT era the whole larynx or the majority of it was included in the CTV1; nowadays there is the tendency to include in the CTV1 only the expanded GTV; however, careful considerations about the depth of invasion, the natural history of disease, the presence/absence of anatomical barriers (i.e. continuity between pre-epiglottic and para-glottic spaces (Figure 3) and the quality of the imaging should always be taken into consideration; the use of anatomic compartments to define CTV boundaries is more adequate than the use of any arbitrary uniform expansion around the GTV, unless such boundaries are not well-defined, such as the anterior boundary in case of base of the tongue involvement [50]. Thus, the CTV1 corresponds to the GTV plus a margin of $5 \mathrm{~mm}$ to $1 \mathrm{~cm}$ or more, depending on the ways of diffusion or anatomical barriers (i.e. supraglottic tumours extending to the aryepiglottic folds will be outlined extending the superior margin of the CTV to $2 \mathrm{~cm}$ above the GTV; in case of infiltration of the base of tongue, a structure that does not present anatomical barriers, a margin of $1.5-2 \mathrm{~cm}$ is appropriate) and should not be modified according to a possible response to induction ChT.[140]. In correspondence of anatomical barriers GTV to CTV expansion should not exceed those structures (eg, prevertebral fascia, bone). In case of doubt of submucosal extension, it is better to enlarge the volumes to reduce the risk of recurrence.

2. The level of complexity required for the irradiation of laryngeal cancer is highly variable and IMRT may provide distinct advantages over 3DCRT in sparing OARs (parotids, especially when level IIb is part of the target, carotids for early stage lesions) and covering the target (avoiding field junctions and irradiating the subglottis especially in patients with a 'short' neck'). Though there are several dosimetric and even preliminary clinical experience with IMRT for T1-2 glottic cancers $[141,142]$ or for locoregionally advanced glottic and supraglottic cancers [121-123], the clinical benefits of IMRT are usually speculative and the standard of care remains 3DCRT.

Table 14 provides guidelines for contouring primary tumor CTVs on planning imaging:

\section{Postoperative treatments}

In the postoperative setting, features that are usually considered predictors of local relapse are: i. close or positive margins; ii. pT4; iii. extracapsular extension of the neck nodes. Other features (i.e. perineural spread) are less recognized and need to be considered on a caseto-case basis. In order to outline postoperative volumes, pre-surgery imaging studies and operative note(s) should be carefully reviewed. Moreover, the natural history of the disease plays also an important role.

In case of subglottic or soft tissue extension, the region of the stoma should be included in CTV2, while for upward lesions (i.e. lesions with significant anterior extension in the pre-epiglottic space) the base of tongue needs to be included in CTV2.

After subtotal laryngectomy, the decision to include the larynx within the low dose level (even in absence of high risk features), simply because it has been part of the operative bed, is controversial [135]. However, regardless whether the larynx is included or not, careful planning should avoid unnecessary overdosing of the larynx (>50 Gy) in absence of specific indication (e.g. if the decision to irradiate a removed level II node with extracapsular extension is made, the larynx should not receive a dose higher than 50 Gy even though the lymph-nodal area at risk needed a dose higher than 60 Gy). For high risk patients (R1 and pT4) CTV1 should include the whole remnant larynx with cranial and caudal extent of resection (e.g. subglottic extension) and the site of dissected positive lymph-nodes. 
Table 14 Guidelines for contouring larynx (according to subsites)

\begin{tabular}{|c|c|c|c|c|c|c|}
\hline $\begin{array}{l}\text { Supraglottic } \\
\text { larynx }\end{array}$ & Superior limit & Inferior limit & Ipsilateral limit & Contralateral limit & Anterior limit & $\begin{array}{l}\text { Posterior } \\
\text { limit }\end{array}$ \\
\hline CTV 1 & $\begin{array}{l}\mathrm{GTV}+0.5-1 \mathrm{~cm} \\
\text { margin }\end{array}$ & idem & Idem & idem & Idem & idem \\
\hline CTV 2 & $\begin{array}{l}\text { Epiglottis, base of } \\
\text { tongue ( } 1 \mathrm{~cm} \\
\text { from CTV HD), } \\
\text { arytenoids }\end{array}$ & $\begin{array}{l}\text { Inferior border of } \\
\text { chricoid cartilage }\end{array}$ & $\begin{array}{l}\text { Hyoid bone, thyrohyoid, } \\
\text { omohyoid and sternohyoid } \\
\text { muscle laterally to thyroid } \\
\text { cartilage, chricoid cartilage } \\
\text { (plus pyriform sinus } \\
\text { depending on GTV) }\end{array}$ & $\begin{array}{l}\text { Hyoid bone, } \\
\text { thyrohyoid, } \\
\text { omohyoid and } \\
\text { sternohyoid muscle } \\
\text { laterally to thyroid } \\
\text { cartilage, chricoid } \\
\text { cartilage }\end{array}$ & $\begin{array}{l}\text { Hyoid bone, thyroid } \\
\text { cartilage, omohyoid and } \\
\text { sternohyoid muscle } \\
\text { anterior to pre- } \\
\text { epiglottic space, thyroid } \\
\text { cartilage, chricoid } \\
\text { cartilage }\end{array}$ & $\begin{array}{l}\text { Epiglottis, } \\
\text { posterior } \\
\text { limit of } \\
\text { thyroid } \\
\text { cartilage, } \\
\text { arythenoids }\end{array}$ \\
\hline CTV 3 & $\begin{array}{l}\text { Optional (add } \\
\text { margin from } \\
\text { CTV 2) }\end{array}$ & Idem & Idem & Idem & Idem & idem \\
\hline \multicolumn{7}{|l|}{ Glottic larynx } \\
\hline CTV1 & $\begin{array}{l}\mathrm{GTV}+0.5-1 \mathrm{~cm} \\
\text { margin }\end{array}$ & idem & Idem & idem & idem & idem \\
\hline CTV2 & $\begin{array}{l}\text { sub-hyoid } \\
\text { epiglottis and pre- } \\
\text { epiglottis space } \\
\text { anterior to sub- } \\
\text { hyoid epiglottis, } \\
\text { hyoid bone, } \\
\text { arytenoid }\end{array}$ & $\begin{array}{l}\text { Inferior border of } \\
\text { cricoid cartilage }\end{array}$ & $\begin{array}{l}\text { Hyoid bone, thyrohyoid, } \\
\text { omohyoid and sternohyoid } \\
\text { muscle laterally to thyroid } \\
\text { cartilage, cricoid cartilage } \\
\text { (plus pyriform sinus and } \\
\text { thyroid gland depending } \\
\text { on GTV) }\end{array}$ & $\begin{array}{l}\text { Hyoid bone, } \\
\text { thyrohyoid, } \\
\text { omohyoid and } \\
\text { sternohyoid muscle } \\
\text { laterally to thyroid } \\
\text { cartilage, cricoid } \\
\text { cartilage }\end{array}$ & $\begin{array}{l}\text { Hyoid bone, thyroid } \\
\text { cartilage, omohyoid and } \\
\text { sternohyoid muscle } \\
\text { anterior to pre- } \\
\text { epiglottic space, thyroid } \\
\text { cartilage, cricoid } \\
\text { cartilage }\end{array}$ & $\begin{array}{l}\text { Epiglottis, } \\
\text { posterior } \\
\text { limit of } \\
\text { thyroid } \\
\text { cartilage, } \\
\text { arythenoids }\end{array}$ \\
\hline CTV 3 & $\begin{array}{l}\text { Optional (add } \\
\text { margin from } \\
\text { CTV 2) }\end{array}$ & Idem & Idem & Idem & Idem & idem \\
\hline \multicolumn{7}{|c|}{ Subglottic larynx } \\
\hline CTV 1 & $\begin{array}{l}\mathrm{GTV}+0.5-1 \mathrm{~cm} \\
\text { margin }\end{array}$ & idem & Idem & idem & idem & idem \\
\hline CTV2 & $\begin{array}{l}\text { Epiglottis, base of } \\
\text { tongue }(1 \mathrm{~cm} \\
\text { from CTV HD), } \\
\text { arytenoids }\end{array}$ & $\begin{array}{l}\text { Superior limit of first } \\
\text { tracheal cartilage } \\
\text { (or lower depending } \\
\text { on GTV) }\end{array}$ & $\begin{array}{l}\text { Hyoid bone, thyrohyoid, } \\
\text { omohyoid and sternohyoid } \\
\text { muscle laterally to thyroid } \\
\text { cartilage, chricoid cartilage, } \\
\text { homolateral thyroid gland }\end{array}$ & $\begin{array}{l}\text { Hyoid bone, } \\
\text { thyrohyoid, } \\
\text { omohyoid and } \\
\text { sternohyoid muscle } \\
\text { laterally to thyroid } \\
\text { cartilage, chricoid } \\
\text { cartilage }\end{array}$ & $\begin{array}{l}\text { Hyoid bone, thyroid } \\
\text { cartilage, omohyoid and } \\
\text { sternohyoid muscle } \\
\text { anterior to pre- } \\
\text { epiglottic space, thyroid } \\
\text { cartilage, chricoid } \\
\text { cartilage }\end{array}$ & $\begin{array}{l}\text { Retrochrycoid } \\
\text { region, } \\
\text { arythenoids, } \\
\text { (upper } \\
\text { oesophageal } \\
\text { opening } \\
\text { depending } \\
\text { on GTV) }\end{array}$ \\
\hline CTV 3 & $\begin{array}{l}\text { Optional (add } \\
\text { margin from CTV 2) }\end{array}$ & Idem & Idem & Idem & Idem & idem \\
\hline
\end{tabular}

\section{Lymphnode-level contour}

Anatomical considerations.

\section{Supraglottic larynx}

The lymphatic drainage terminates in the ipsilateral level II nodes while a second component extends lateral and drains into nodes located at the junction of Levels II and III. There is occasionally a third component that drains into the nodes located in Level III nodes.

Tumours involving the supraglottic larynx are at risk of crossing lymphatic drainage. The risk of palpable lymph nodes at presentation is higher for epi-laryngeal tumours than for the rest of supraglottic one [143].

\section{Glottic larynx}

The true vocal cords (TVC) form a natural barrier between the supraglottic and infraglottic larynx due to its paucity of lymphatic draining. At any rate, the lymphatic drainage of sovraglottic or subglottic larynx can be involved by advanced TVC carcinoma.

\section{Subglottic larynx}

Lymphatics from the subglottic larynx drain to the mid and lower jugular lymph nodes (levels III and IV) and to the prelaryngeal (cricothyroid or Delphian) node. Subsequently, the pretracheal and paratracheal lymph nodes can be involved [144].

Tables 15 and 16 provide guidelines for contouring neck levels either in the case of negative or positive nodes on the imaging:

Historical perspectives

1. For $\mathrm{T} 2 \mathrm{~N} 0$ of the glottis, the standard recommendation is to treat the larynx only, but the actual results are 
Table 15 Guidelines for contouring neck levels (negative on the imaging)

\begin{tabular}{|c|c|c|c|c|}
\hline $\begin{array}{l}\text { Laryngeal } \\
\text { Site }\end{array}$ & $\begin{array}{l}\mathrm{T} \\
\text { stage }\end{array}$ & $\begin{array}{l}\text { Levels to be } \\
\text { included in } \\
\text { CTV HR }\end{array}$ & $\begin{array}{l}\text { Levels to be } \\
\text { included in } \\
\text { CTV LR }\end{array}$ & Remarks \\
\hline \multirow[t]{4}{*}{ Supraglottic } & $\mathrm{T} 1-2$ & II-III (bil) & IV (bil), & \\
\hline & T3-4 & II-III (bil) & IV (bil), VI & \\
\hline & & & $\begin{array}{l}\text { VII only if } \\
\text { subglottic } \\
\text { extension }\end{array}$ & \\
\hline & & & $\begin{array}{l}\text { RP only if } \\
\text { extension to } \\
\text { pharynx }\end{array}$ & \\
\hline \multirow[t]{6}{*}{ Glottic } & $\mathrm{T} 1$ & None & & \\
\hline & $\mathrm{T} 2$ & $\begin{array}{l}\text { None/ } \\
\text { Questionable }\end{array}$ & & $\begin{array}{l}\text { Levels II and III if } \\
\text { supragl extLevels III }\end{array}$ \\
\hline & & (see text) & & and IV if subgl ext \\
\hline & T3-4 & II-III (bil) & IV (bil), VI & \\
\hline & & & $\begin{array}{l}\text { VII only if } \\
\text { subGL ext }\end{array}$ & \\
\hline & & & $\begin{array}{l}\text { RP only if ext } \\
\text { to pharynx }\end{array}$ & \\
\hline \multirow[t]{2}{*}{ Subglottic } & $\mathrm{T} 1-2$ & III-IV (bil) & & VII optional \\
\hline & T3-4 & II-IV (bil) & $\begin{array}{l}\mathrm{VI}, \mathrm{VII}, \mathrm{RP} \text { only } \\
\text { if ext to } \\
\text { pharynx }\end{array}$ & \\
\hline
\end{tabular}

based on pre-IMRT cases. Conventional RT used to irradiate with two lateral opposing fields. Authors showed that portions of the neck lymphatic chain where inadvertently treated $[59,133]$. Therefore, it is advisable, in common practice, to irradiate levels II-III and III-IV especially when lesions extend into the supra or sub-glottis.

2. For primary lesions with subglottic involvement and clinically detectable lower neck nodes, the upper mediastinum (down to the level of the carina) was prophylactically covered with AP/PA fields. Therefore, inclusion of level VII in the CTV3 is advised in case of subglottic extension with significant and lower neck disease.

3. In the case of No, level IIb should not be irradiated.

Planning remarks

1. In case of suspicious neck nodes (as previously defined) it is unclear whether only the suspicious finding or the whole level should be included in the CTV2. For nodes belonging to lymph node stations different from ipsilateral levels II and III, the suspicious finding and not the whole level should be contoured as CTV2.

2. For lymph nodes that show gross extracapsular disease, a margin of 5[41]-10[53] mm around
Table 16 Guidelines for contouring neck levels (positive on imaging)

\begin{tabular}{|c|c|c|c|c|}
\hline $\begin{array}{l}\text { Laryngeal } \\
\text { Site }\end{array}$ & $\begin{array}{l}\text { TN } \\
\text { stage }\end{array}$ & $\begin{array}{l}\text { Levels to be } \\
\text { included in } \\
\text { CTV } 2\end{array}$ & $\begin{array}{l}\text { Levels to be included } \\
\text { in CTV } 3\end{array}$ & Remarks \\
\hline Supraglottic & $\begin{array}{l}\mathrm{T} 1-2- \\
\mathrm{N}+\end{array}$ & II-II (bil) & $\begin{array}{l}\text { IV bilat, } V \text { (on the side } \\
\text { of positive neck) }\end{array}$ & \\
\hline Glottis & $\mathrm{T} 2 \mathrm{~N}+$ & II-III (bil) & $\begin{array}{l}\text { IV bilat, } V \text { (on the side } \\
\text { of positive neck) }\end{array}$ & \\
\hline \multirow[t]{2}{*}{ Subglottic } & $\begin{array}{l}\text { T1-2 N } \\
+\end{array}$ & III-IV (bil) & $\begin{array}{l}V \text { (on the side of } \\
\text { positive neck), }\end{array}$ & \\
\hline & & & VII & \\
\hline Glottis/ & \multirow{5}{*}{$\begin{array}{l}\text { T3-4 N } \\
+\end{array}$} & \multirow{5}{*}{ II-IV (bil) } & Ilb if Ila positive, Vl, & \\
\hline Supraglottic/ & & & $\begin{array}{l}V \text { (on the side of } \\
\text { positive neck), }\end{array}$ & \\
\hline \multirow[t]{3}{*}{ Subglottic } & & & $\begin{array}{l}\text { IB only on the side } \\
\text { level II is pos*, }\end{array}$ & \\
\hline & & & VII only if subGL ext & \\
\hline & & & $\begin{array}{l}\text { RP only if ext to } \\
\text { pharynx }\end{array}$ & \\
\hline
\end{tabular}

the visible GTV is usually added; in case of muscular infiltration by a pathological lymph node (i.e. sternocleidomastoid muscle), it is recommended to include at least the portion of the muscle surrounding the node [47]. Similarly, it would be appropriate to include the whole muscle (i.e. sternocleidomastoid muscle) in the lowest dose level when grossly infiltrated at some level.

3. After surgical removal of a lymph-node with extracapsular extension, the initial location of the node needs to be identified; careful planning should avoid underdosing of the surgical scar close to the pre-surgery location of the node (sometimes $3-5 \mathrm{~mm}$ skin bolus is necessary).

4. Subglottic cancer, transglottic cancer, and glottic cancer with subglottic extension have a higher risk of para-tracheal nodes involvement; for $\mathrm{T}>2$ even in N0 patients, this level should be included in CTV3 $[57,145]$.

5. Ipsilateral Ib nodal level and parapharyngeal space extending to retrostyloid space should be included if level II nodes are positive.

\section{Paranasal sinuses and nasal cavity}

\section{Target definition remarks}

RT may be indicated as postoperative (i.e. adenocarcinomas) or definitive treatment with or without concomitant CT. Whereas the definitive treatment leads to the irradiation of the usual 3 CTVs as described in the general part, the previous surgical approach (midfacial degloving, lateral rhinotomy, craniofacial, or endoscopic) 
may complicate the defintion of the volume boundaries. Detailed description of the surgical procedure and pathology report is mandatory. In the postoperative setting, there is no identifiable GTV and thus CTV1 is not available. CTV is represented by all areas at risk of containing residual microscopic disease and the choice between HR and LR depends on the risk for each sub-volume.

\section{Dose/fractionation remarks}

Table 17 shows the commonly used fractionation regimens:

\section{Primary-tumour contour}

Table 18 describes the limits of the CTV2 for ethmoid and maxillary regions, according the suggestions of Stratt et al. [149].

\section{Planning remarks}

1. In regions where the GTV is flanked by anatomic barriers (i.e. intact bone), no margin is usually added. In regions where GTV involves compartments enclosed by bone (i.e. maxillary sinus), the whole compartment is contoured as CTV1.

2. When the tumour is in proximity of radiologically defined spaces known to poorly resist to invasion (i.e. masticator or para-pharyngeal spaces) either the entire space or at least part of it should be contoured as CTV2/3. The former is usually reserved for the part close/next to the tumour while the latter for the remaining part.

3. Similarly, when the tumour is abutting the medial wall of the orbit or there is minimal orbital invasion, the medial part (including the rectus medialis muscle) of the orbit has to be included into the CTV2/3.

4. The choice of the regions at risk for microscopic disease depends on the location of the primary tumour, its extension/stage, and pathology. In general, the palate, alveolar ridge, nasal cavity, and the nasopharynx are included in the CTV2/3 in case of maxillary sinus tumours, and the medial orbit in maxillary/ethmoid-sinus cancers. The pterygopalatine fossa and infratemporal fossa, frequently at risk of subclinical disease, are included in the CTV2/LR. Superior lesions require CTV extension to the sphenoid sinus and foramen rotundum at the base of skull to accommodate potential involvement of the maxillary nerve.

5. If MRI suggests neural involvement, the CTV2/3 should be extended to include the cavernous sinus. For lesions in the upper nasal cavity and ethmoid sinuses, the cribriform plate and a rim of the frontal lobe are included in the CTV2/LR. The anterior cranial fossa is included in case of intracranial extension [16].
6. As a general rule, after induction $\mathrm{CT}$, the original location of the tumour (and not the residual) represents the CTV1.

7. In the postoperative setting, CTV2 consists of the resection cavity plus a variable margin according to the principles of a "compartment-related CTV" as described above. All surgically violated regions should be included in the lowest dose level CTV.

8. In case of adenoid cystic carcinoma, attention should be paid to the neural spread and, hence, RT volumes must encompass the afferent and efferent local nerves up to the skull base.

9. Esthesioneuroblastomas arise in the superior nasal cavity and, even at early stages, tend to invade the cribriform plate and anterior cranial fossa, and therefore, these regions should be encompassed in the target volume.

\section{Lymphnode-level contour}

1. Lymph node metastases are unusual, thus elective treatment of the neck is not mandatory (excluded in the cases of esthesioneuroblastomas, high-grade/ high-stage SCC or whenever the next anatomical regions (e.g. nasopharynx, cheek, gingiva or alveolus) are involved.

2. Lymphatic drainage from the paranasal sinuses is to the retropharyngeal, submandibular, and jugodigastric nodes [57]. Cervical metastases are below $10 \%$ at presentation thus not justifying elective dissection. For the same reason lymphnodes are usually not included in any CTV unless involved or at risk. The risk of involvement usually depends on the location of the primary tumour and the pathology. Adenocarcinomas and sinonasal undifferentiated cancers (SNUC) rarely spread to lymph nodes; some Authors claim prophylactic neck treatment for esthesioneuroblastomas [150] or SCC of the maxillary sinus $[151,152]$.

3. Once prophylactic neck treatment is indicated, the side of the neck and the levels to be contoured depend on both the location of the tumour and its pathology. For maxillary sinus, levels IB and II represent the first echelon; for esthesioneuroblastomas, a comprehensive neck irradiation (levels IB-V) is the rule. Bilateral retropharyngeal nodes irradiation should be considered.

Planning remarks

1. After CTV to PTV expansion, overlap between PTV and OAR is frequent and optimal target coverage is often challenging. 
Table 17 Suggested fractionation regimens for para-nasal sinus and nasal cavity

\begin{tabular}{|c|c|c|c|c|c|c|}
\hline Definitive & & D (Gy) & d (Gy) & fxs & OTT (wks) & Comment \\
\hline \multirow[t]{2}{*}{ Daly [146] } & GTV & 69.96 & 2.12 & 33 & 6.5 & \\
\hline & CTV1 & 70 & 2 & 35 & 7 & \\
\hline \multirow[t]{2}{*}{ Wiegner [147] } & & 66 & 2.2 & 33 & 6.5 & \\
\hline & CTV2 & 63 & 1.8 & 35 & 7 & \\
\hline \multirow[t]{2}{*}{ Daly [146] } & & 59.4 & 1.8 & 33 & 6.5 & \\
\hline & CTV3 & 58.1 & 1.66 & 35 & 7 & \\
\hline Daly [146] & & 54.12 & 1.64 & 33 & 6.5 & \\
\hline \multicolumn{7}{|c|}{ Postoperative setting } \\
\hline & CTV2 & 63 & 1.8 & 35 & 7 & \\
\hline \multirow[t]{2}{*}{ Hoppe 2008 [148] } & & $60-66$ & $2-2.2$ & $30-33$ & 6 & Especially for adenocarcinoma \\
\hline & CTV3 & 58.1 & 1.66 & 35 & 7 & \\
\hline Hoppe [148] & & $54-54.12$ & $1.8-1.64$ & $30-33$ & 6 & \\
\hline
\end{tabular}

2. In general planning priorities are set to avoid a risk of late toxicity $>10 \%$ on selected OARs as brain, brainstem, chiasm and optic nerves.In the planning process, any attempt should be made to maintain coverage of CTV1 while compromising the coverage of PTV in order to allow minor variations in selected OAR irradiation (i.e. V95\% of CTV1 is $>95 \%$ while PTV1 coverage is $93 \%$ and optic nerve Dmax is 59.9 Gy).

3. Proton Beam Therapy has shown good results and acceptable toxicity especially in locally advanced inoperable paranasal tumours $[153,154]$.

\section{Salivary glands}

\section{Target definition remarks}

Salivary gland tumours are usually treated with surgery. Curative RT alone is an option (even if the odds' local control is relatively low) for patients with technically unresectable disease or inoperable for medical reasons or who refuse surgery.

Risk factors that support postoperative RT include T3/ T4 disease and or any of the following $[155,156]$ :

- Incomplete or close resection margins
- High grade histology

- Recurrent disease

- Peri-neural invasion

- Nodal involvement

\section{Pathology remarks}

Salivary gland tumours include a variety of both benign and malignant tumours that can involve both minor and major salivary glands. In major salivary glands the most frequent benign tumour is pleomorphic adenoma, whereas the most frequent malignant hystology is mucoepidermoid carcinoma; adenoid cystic carcinoma is the most frequent malignant tumour in minor salivary glands. Diagnosis is often difficult and experienced pathologist is needed to interpret fine needle aspiration cytology. Table 19 summarizes the most important pathology variants and the role of RT:

External beam RT with photons is rarely a curative option since local control in malignant salivary gland tumours is dose dependent. Considering that high doses are needed to achieve local control, most malignant salivary gland tumours would probably benefit from the use of particle therapy. However, although locoregional control after neutron therapy seems to be higher than

Table 18 Suggested CTV2 for ethmoid and maxillary sites

\begin{tabular}{|c|c|c|c|c|}
\hline & Superior & Inferior & Lateral & Posterior \\
\hline \multirow[t]{2}{*}{ Ethmoid } & $\begin{array}{l}\text { Cribriform plate should be } \\
\text { included. }\end{array}$ & \multirow{2}{*}{$\begin{array}{l}\text { The inferior turbinate; In the case } \\
\text { that the inferior border of the GTV } \\
\text { allows a 10-mm margin around the } \\
\text { original disease, the entire hard pal- } \\
\text { ate does not need to be included. }\end{array}$} & \multirow{2}{*}{$\begin{array}{l}\text { The nasal cavity, ethmoid } \\
\text { sinuses, and the ipsilateral } \\
\text { maxillary sinus and when } \\
\text { indicated the volume should } \\
\text { extend to the rectus muscle. }\end{array}$} & \multirow{2}{*}{$\begin{array}{l}\text { Include the sphenoid sinus. The } \\
\text { retropharyngeal lymph nodes } \\
\text { should be encompasses if the } \\
\text { tumour extended close to the } \\
\text { nasopharynx or if there are } \\
\text { metastatic neck nodes from an } \\
\text { ethmoidal carcinoma. }\end{array}$} \\
\hline & $\begin{array}{l}\text { In the case it was been } \\
\text { resected the margin should } \\
\text { encompass all the initial } \\
\text { GTV including the dura or } \\
\text { the dural graft. }\end{array}$ & & & \\
\hline Maxillary & & $\begin{array}{l}\text { The inferior border of the maxilla } \\
\text { and the hard palate but should } \\
\text { encompass a 10-mm margin } \\
\text { around the initial GTV. }\end{array}$ & $\begin{array}{l}\text { Medial aspect should be the } \\
\text { nasal septum, unless violation of } \\
\text { midline structures occurs. }\end{array}$ & $\begin{array}{l}\text { The pterygopalatine and the } \\
\text { infratemporal fossa should be } \\
\text { included, paying special attention } \\
\text { to encompass the masticator space } \\
\text { and the infraorbital fissure. }\end{array}$ \\
\hline
\end{tabular}


after photon irradiation, severe late toxicity has been observed while OS was equal. Promising results were found in a dose escalation study in locally advanced adenoid cystic carcinoma. Patients were treated with stereotactically guided or photon IMRT (45-54Gy) and a carbon ion boost of $18 \mathrm{GyE}$. The results are similar to those obtained with neutrons alone but with lower late toxicity profile [157].

\section{Dose/fractionation remarks}

Table 20 summarizes the most commonly used postoperative fractionation regimens:

\section{Primary tumour contour}

1. A bolus over the scar region is indicated in the case of skin invasion, for superficially located tumours of the parotid or submandibular glands and/or in case of tumour spillage/ capsular rupture.

2. Adenoid cystic tumours have the distinct propensity for perineural infiltration (facial, trigeminal, hypoglossal, lingual nerve) and skull base involvement; in case of 'named' nerve invasion, CTV3 must track the course of the nerve as back as to its entry in the skull (base of skull). The addition of concomitant adjuvant $\mathrm{CT}$ is still investigational.

3. The CTV is a function of the location of the tumour (Table 21), its extension and histological risk factors; for low grade tumours, only the tumour site (i.e. parotid bed) is at risk; for high grade tumours, CTV2 includes the initial site of disease, while CTV3 should cover the whole surgical bed.

4. For parotid gland tumours, a document online describes target volume definition of the parotid bed and indications for ipsilateral neck irradiation for patients entering the COSTAR trial (COchlear Sparing Therapy And Conventional Radiation: A Multicentre Randomised Study Of Cochlear Sparing Intensity Modulated RT Versus Conventional RT In Patients With Parotid Tumours)

http://aktinotherapeutis.gr/wp-content/uploads/doctors/COSTAR_Outlining_Guidelines.pdf

4. The parotid gland extends from the zygomatic arch superiorly to beyond the lower border of the mandible inferiorly. Posteriorly, the gland dips in the space between the mandible and the mastoid, with the adjoining external auditory meatus intimately surrounded by the gland in its free borders, that is, anteriorly and inferiorly. On a deeper plane, the parotid is related to the styloid process and the muscles connected to it (Figure 4). Local infiltration of tissues adjacent to the parotid gland is the main pattern of spread. This follows the anatomical borders of the parotid gland and in cases of perineural invasion, the facial nerve to the stylomastoid foramina.

5. CTV2 for parotid tumours includes: the parotid bed and any adjacent tissues at risk of microscopic spread.

a. Areas at risk of soft tissue extension are: infratemporal fossa, parapharyngeal space, masseter and digastric muscle, skin.

b. Bone infiltration-at risk areas include: lateral part of the floor of middle cranial fossa, neck of mandible, external auditory meatus, inferior surface of styloid process.

\section{Lymphnode-level contour}

1. Elective nodal irradiation should be considered in any of the following [158]:

a. High grade tumours

b. T3/T4 stage

c. Histological subtype

i. Squamous cell carcinomas

ii. Adenocarcinomas

iii. Undifferentiated carcinomas,

iv. High grade mucoepidermoid carcinomas

v. Salivary duct carcinomas

2. In case of risk of subclinical disease, if the primary tumour is dissected, the lymph node levels at risk should be dissected as well (surgical/pathological staging of the neck is usually preferred to elective treatment of undissected neck).

3. After surgery, planning should avoid underdosing of the skin especially when capsular rupture is present (bolus over the scar).

4. Levels Ib, Ila IIb, RP ipsilateral nodal stations (commonly in tumor bed) should be included in CTV2 for parotid tumors.

5. Levels III, IV and V ipsilateral nodal stations should be included in CTV3 for parotid tumors when high grade features are present, T3-T4, and the histological type listed in point 1 if neck is undissected $[159,160]$.

6. There is no indication for bilateral elective neck treatment.

\section{Neck metastases from unknown primary (cTx) General remarks}

Metastatic cervical nodes of unknown primary origin represent a very heterogeneous entity. Squamous cell carcinoma is the more frequent histological type, followed by adenocarcinoma and undifferentiated carcinoma. 


\begin{tabular}{|c|c|c|}
\hline Category & Variant & RT \\
\hline $\begin{array}{l}\text { Benign mixed } \\
\text { tumors }\end{array}$ & $\begin{array}{l}\text { i.e. pleomorphic } \\
\text { adenoma }\end{array}$ & $\begin{array}{l}\text { Only for recognized tumour spill; } \\
\text { transformation into malignant; } \\
\text { recurrent (controversial) }\end{array}$ \\
\hline \multirow[t]{2}{*}{$\begin{array}{l}\text { Malignant, low } \\
\text { grade }\end{array}$} & $\begin{array}{l}\text { Acinic cell } \\
\text { carcinoma }\end{array}$ & \multirow{2}{*}{$\begin{array}{l}\text { Only for incomplete resection } \\
\text { (i.e. close to CN VII), positive or } \\
\text { close resection margins; } \\
\text { capsule rupture; recurrent }\end{array}$} \\
\hline & $\begin{array}{l}\text { Mucoepidermoid } \\
\text { carcinoma }\end{array}$ & \\
\hline \multirow[t]{5}{*}{$\begin{array}{l}\text { Malignant high } \\
\text { grade }\end{array}$} & $\begin{array}{l}\text { Mucoepidermoid } \\
\text { carcinoma }\end{array}$ & \multirow{5}{*}{$\begin{array}{l}\text { Always postop RT except in } \\
\text { adenoid cystic carcinoma and } \\
\text { mucoepdermoid in absence } \\
\text { of risk factors. }\end{array}$} \\
\hline & Adenocarcinoma & \\
\hline & SCC & \\
\hline & Malignant mixed & \\
\hline & Adenoid cystic & \\
\hline
\end{tabular}

When pathology is different from squamous cell carcinoma (eg melanoma, lymphoma, adenocarcinoma), a primary arising in the chest, thyroid or salivary gland cancer should be suspected and treatment should be planned accordingly (the following guidelines would not apply).

Here we consider only SCC or undifferentiated carcinoma.

There are some correlations between the location of the node and the primary site:

1. superficial parotid: skin;

2. level Ib: oral cavity;

3. level Va: NPC;

4. level IV: chest (or abdomen)

More than $50 \%$ of primaries are discovered by physical examination and assessment under anaesthesia conducted by experienced ENTs (this data refers to pre-PET era) $[161]$; $50-80 \%$ of primaries are found in the oropharynx; there is a strong correlation between HPV, cystic nodes and oropharyngeal primary [162], but up to

Table 20 Commonly used postoperative regimens

\begin{tabular}{llllll}
\hline & $\mathbf{D}(\mathrm{Gy})$ & $\mathbf{d}(\mathrm{Gy})$ & $\mathbf{f x s}$ & $\mathbf{O T T}$ (wks) & Comment \\
\hline CTV2 & 66 & 2 & 33 & 6.5 & {$[155]$} \\
& 63 & 1.8 & 35 & 7 & \\
CTV3 & 60 & 2 & 30 & 6 & {$[155]$} \\
& 54 & 1.8 & 30 & 6 & \\
& 58.1 & 1.66 & 35 & 7 & \\
& 59.4 & 1.8 & 33 & 6.5 &
\end{tabular}

In general the radiosensitivity of salivary gland tumours depends on their pathology; doses for SCC are similar to SCC of other districts; for adenoid cystic doses in the order of $66 \mathrm{~Gy}$ and $60 \mathrm{~Gy}$ (at $2 \mathrm{~Gy}$ per fr) are recommended for CTV2 and CTV3, respectively [155] A dose of 60 Gy for postoperative treatment of high grade tumours has been suggested also by Chen et al. [158].
Table 21 Suggested volumes (surgical bed) at high risk

\begin{tabular}{lllll}
\hline Site & Anterior & Lateral & Medial & Posterior \\
\hline Parotid surgical bed & $\begin{array}{l}\text { Masseter } \\
\text { muscle }\end{array}$ & $\begin{array}{l}\text { Soft tissue } \\
\text { of neck }\end{array}$ & $\begin{array}{l}\text { Styloid } \\
\text { process }\end{array}$ & $\begin{array}{l}\text { Mastoid } \\
\text { bone }\end{array}$ \\
$\begin{array}{l}\text { Submandibular } \\
\text { surgical bed }\end{array}$ & $\begin{array}{l}\text { Follow clips if leaved by surgeon otherwise } \\
\text { and use the contralateral submandibular } \\
\text { gland as a guide. }\end{array}$ & \\
\hline
\end{tabular}

$25 \%$ of patients may have primary disease below the clavicles (lungs). EBV testing may help determine possible primary location. There is no advantage for repeated Direct Laryngoscopy if negative initially [163].

More than FNA (e.g. incisional/excisional biopsy) is considered 'neck violation' and should be avoided. Injudicious removal of a metastatic node causes surgical scarring which may prevent or preclude subsequent surgical dissection of the lymph node bearing area. Above all, this procedure may delay the proper treatment.

Unilateral or bilateral tonsillectomy should be performed including excision of eventual remnant tonsillar tissue. In the absence of panendoscopic detectable lesions, ipsilateral tonsillectomy can discover carcinoma in about a quarter of the patients [164]. If physical examination shows mucosal abnormalities the detection rate rises to $40 \%$. It is still controversial if tonsillectomy should be bilateral or unilateral. In favour of bilateral tonsillectomy, some Authors report that the rate of contralateral spread of metastatic cancer from occult tonsil lesions may approach 10\%. A more convincing reason is to avoid asymmetric FDG uptake in the oropharyngeal region by removing only one tonsil that may confound follow up studies. For these reasons, bilateral tonsillectomy is recommended as a routine step in the search for the occult primary in patients presenting with cervical metastasis of SCC and palatine tonsils intact [165]. The discovery of the primary lesion may help the radiation oncologist to better define volumes to be treated and their respective dose. This ultimately would help to increase the odds of cure and minimize the risk of side effects. If physical examination and other imaging modalities are negative, PET may discover new primaries in an additional $25 \%$ of patients $(5-73 \%)$, nodes in $\approx 15 \%$ and distant metastases in $\approx 10 \%$ [166]. Because FDGPET detects increased metabolic activity, inflammation induced by biopsies may contribute to false-positive results if PET is obtained after direct laryngoscopy/ biopsy [167].

General treatment strategy

There are 2 main clinical scenarios:

\section{MACROSCOPIC TUMOUR RESIDUAL AFTER INITIAL EVALUATION: Surgery vs RT \pm CT}




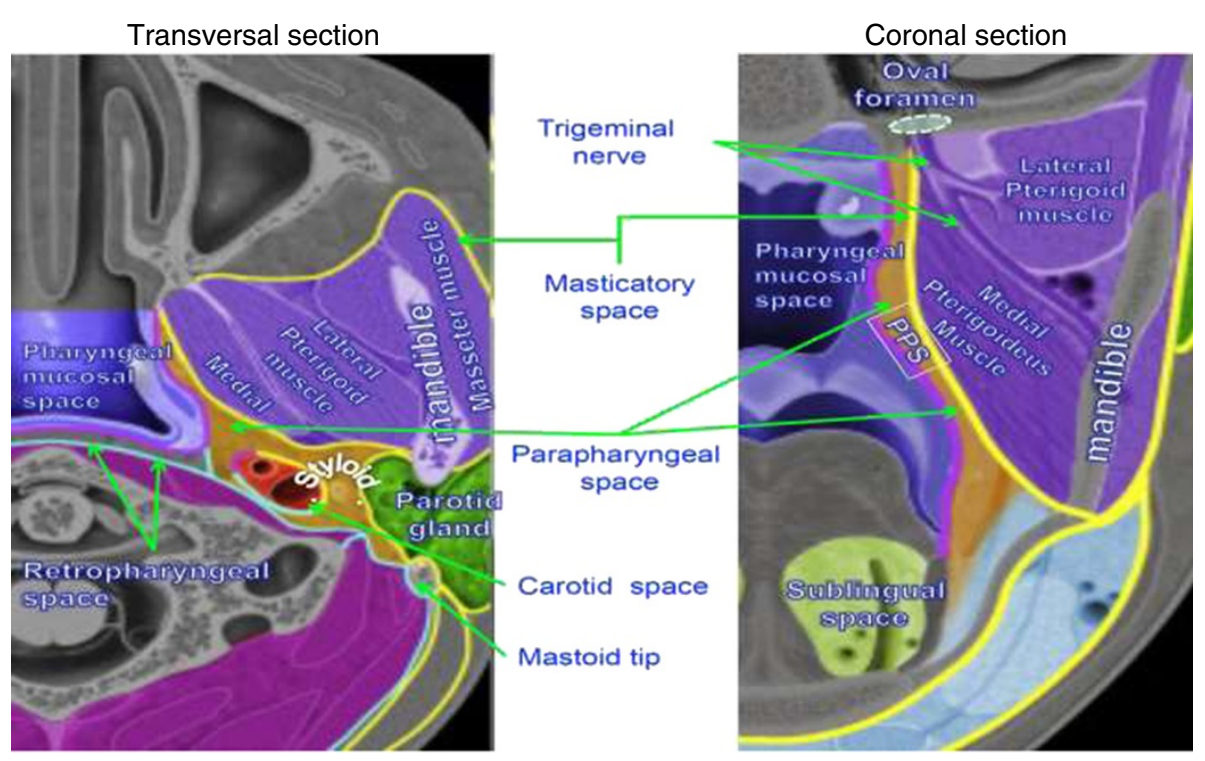

Figure 4 Parapharyngeal space (transversal and coronal sections).

In favour of neck surgery stand the following remarks:

1. If the patient most likely needs surgery after RT or chemoRT (i.e. bulky node);

2. If the patient may be potentially cured by surgery alone (i.e. small $<3 \mathrm{~cm} /$ single node);

3. Surgery permits concomitant teeth extractions and Direct Laringoscopy;

4. Surgery allows for a better staging of the neck and pathology of node level involvement;

5. If more tissue is required and pathology of nodal diffusion is uncertain.

However, surgery may add extra morbidity especially if subsequent RT is necessary.

In favour of $\mathrm{RT} \pm \mathrm{CT}$ stand the following remarks:

1. If RT or CT-RT are potentially curative in patient that would need postoperative RT anyhow (i.e. multiple small nodes);

2. The use of RT or CT-RT without surgery on the neck allows for a better oxygenation of the potential mucosal site of primary;

Table 22 Suggested fractionation regimens for Unknown Primary (macroscopic disease present)

\begin{tabular}{llllll}
\hline & D (Gy) & $\mathbf{d}($ Gy) & Fxs & OTT (wks) & Comment \\
\hline CTV1 & 70 & 2 & 35 & 7 & \\
& 66 & 2.2 & 30 & 6 & {$[168]$} \\
CTV2 & 63 & 1.8 & 35 & 7 & \\
CTV3 & 58.1 & 1.66 & 35 & 7 & \\
& 54 & 1.8 & 30 & 6 & {$[168]$} \\
\hline
\end{tabular}

3. It permits better evaluation of tumour response (especially if CT is used); leaving salvage surgery for non-responders.

\section{NO RESIDUAL MACROSCOPIC DISEASE AFTER INITIAL EVALUATION}

If pN1 AND no ECE (AND no previous neck violation), observation can be appropriate; otherwise, if $\mathrm{pN}>$ 1 or ECE or neck violation, postoperative RT should be recommended.

\section{Target definition remarks}

CTV1 or high disease volume that encompasses the gross tumour volume in the neck if present with a margin;

CTV2 that typically includes the putative primary site(s) considered at high risk of containing microscopic disease; moreover, after surgery, this would include the site of dissected positive lymph nodes;

CTV3 includes the nodal stations that do not contain positive or suspicious nodes after appropriate imaging;

Table 23 Suggested fractionation regimens for Unknown Primary (postoperative setting)

\begin{tabular}{llllll}
\hline & D (Gy) & $\mathbf{d}(\mathrm{Gy})$ & $\mathbf{f x s}$ & OTT (wks) & Comment \\
\hline CTV2 & $60-64$ & 2 & $30-32$ & 6 & (64 Gy if ECE+) [168] \\
& 63 & 1.8 & 30 & 6 & \\
CTV3 & 58.1 & 1.66 & 35 & 7 & \\
& 54 & 1.8 & 30 & 6 & \\
\hline
\end{tabular}


moreover, it would include the putative primary site(s) considered at low risk of containing microscopic disease.

\section{Dose/fractionation remarks}

Tables 22 and 23 show the commonly used fractionation regimens in definitive (macroscopic nodal disease present) and in postoperative settings:

\section{Primary-tumour contour}

1. According to classical teaching, the putative primary tumour may be located in the pharyngeal axis and thus the mucosa of the whole pharynx (nasopharynx, oropharynx and hypopharynx) as well as the larynx would be included in the subclinical dose level; the oral cavity should NOT be routinely included. The extent of the pharynx to be irradiated must be determined on a case-by-case basis [169]:

a. Irradiation of oropharynx alone might be sufficient for an HPV+ patient.

b. Irradiation of nasopharynx alone might be sufficient for an EBV+.

2. The larynx and hypopharynx are considered at low risk if levels III and IV are not involved and PET/CT is negative and level $\mathrm{V}$ is positive and pathology is suspicious for a nasopharyngeal primary or the tumour stains for HPV and/or EBV. In these cases, the dose to the larynx can be lowered to CTV3 or even dropped from any CTV [168,170-173].

\section{Lymphnode-level contour}

1. Traditionally, all neck levels ipsilateral to the positive nodal disease are included in the target volume.

2. With regard to the bilateral neck irradiation, currently there are two points of view:

a. Considering the morbidity induced by extensive irradiation, some Authors consider irradiation of the contralateral neck indicated for a defined subset of patients, e.g., those with bilateral nodal metastases, extensive unilateral involvement with regard to number and levels of nodal metastases (cN2b+), unfavourable grading [164].

b. Other Authors, reporting local control rates with median neck relapse rate ranging from 31 to $63 \%$ after unilateral RT group, compared with a median neck relapse rate ranging from 8 to $49 \%$ in bilateral and pharyngeal mucosa RT group, advocate bilateral neck irradiation [174]. In this case contralateral neck levels II-IV and the retropharyngeal nodes could be included in CTV3 [169].

3. Bilateral retropharyngeal nodes should be included.

4. Ipsilateral level Ib can be excluded if levels II and III are uninvolved.
Competing interests

The authors declare that they have no competing interests.

\section{Authors' contributions}

All authors equally contributed to the writing and editing of the manuscript. All authors read and approved the final manuscript.

\section{Author details}

${ }^{1}$ Radioterapia AO Ospedale di Circolo-Busto Arsizio (VA), Piazzale Professor G. Solaro, 3, 21052 Busto Arsizio, VA, Italy. ${ }^{2}$ Radioterapia IEO-Milano, Milan, Italy. ${ }^{3}$ Radioterapia Az. Ospedaliera S. Croce e Carle-Cuneo, via M. Coppino 26 12100, Cuneo, Italy. ${ }^{4}$ Radioterapia Arcispedale S. Maria Nuova AO-Reggio Emilia, Emilia, Italy. ${ }^{5}$ Radioterapia PO S.Donato-AUSL-Arezzo, Arezzo, Italy.

${ }^{6}$ Radioterapia Azienda Ospedaliera ASL Napoli 1-Napoli, Napoli, Italy.

${ }^{7}$ Radioterapia A.O.U. Maggiore della Carità-Novara, Novara, Italy. ${ }^{8}$ Radioterapia Ospedale Fatebenefratelli, Isola Tiberina-Roma, Roma, Italy. ${ }^{9}$ Radioterapia Policlinico Universitario 'A.Gemelli'-Roma, Roma, Italy. ${ }^{10}$ Radioterapia Università Cattolica del S. Cuore -Campobasso, Roma, Italy. ${ }^{11}$ Dipartimento SBIMOF Sezione di Scienze Radiologiche, Università di Messina, Piazza Pugliatti Salvatore, 1, 98122 Messina, ME, Italy. ${ }^{12}$ Dipartimento di Oncologia, Radioterapia Oncologica, Università di Torino, Turin, Italy. ${ }^{13}$ Oncologia Radioterapica, IRCS S. Martino-IST- Istituto Nazionale per la Ricerca sul Cancro, Università Genova, Genova, Italy. ${ }^{14}$ UOC Radioterapia Istituto Tumori Regina Elena Roma (RM), Roma, Italy.

Received: 19 January 2014 Accepted: 17 November 2014

Published online: 29 December 2014

\section{References}

1. Bekelman JE, Wolden S, Lee N: Head-and-neck target delineation among radiation oncology residents after a teaching intervention: a prospective, blinded pilot study. Int J Radiat Oncol Biol Phys 2009, 73:416-423.

2. Peters LJ, O'Sullivan B, Giralt J, Fitzgerald TJ, Trotti A, Bernier J, Bourhis J, Yuen K, Fisher R, Rischin D: Critical impact of radiotherapy protocol compliance and quality in the treatment of advanced head and neck cancer: results from TROG 02.02. J Clin Oncol Off J Am Soc Clin Oncol 2010, 28:2996-3001.

3. Pignon J-P, le Maître A, Maillard E, Bourhis J: Meta-analysis of chemotherapy in head and neck cancer (MACH-NC): An update on 93 randomised trials and 17,346 patients. Radiother Oncol 2009, 92:4-14.

4. Forastiere AA, Zhang Q, Weber RS, Maor MH, Goepfert H, Pajak TF, Morrison W, Glisson B, Trotti A, Ridge JA, Thorstad W, Wagner H, Ensley JF, Cooper JS: Long-term results of RTOG 91-11: a comparison of three nonsurgical treatment strategies to preserve the larynx in patients with locally advanced larynx cancer. J Clin Oncol 2013, 31:845-852.

5. Brierley R: ASCO annual meeting. Lancet Oncol 2012, 2012(13):665-666.

6. Worden FP, Kumar B, Lee JS, Wolf GT, Cordell KG, Taylor JMG, Urba SG, Eisbruch A, Teknos TN, Chepeha DB, Prince ME, Tsien CI, D'Silva NJ, Yang K, Kurnit DM, Mason HL, Miller TH, Wallace NE, Bradford CR, Carey TE: Chemoselection as a strategy for organ preservation in advanced oropharynx cancer: response and survival positively associated with HPV16 copy number. J Clin Oncol 2008, 26:3138-3146.

7. Worden FP, Moyer J, Lee JS, Taylor JMG, Urba SG, Eisbruch A, Teknos TN, Chepeha DB, Prince ME, Hogikyan N, Lassig AAD, Emerick K, Mukherji S, Hadjiski L, Tsien Cl, Miller TH, Wallace NE, Mason HL, Bradford CR, Wolf GT: Chemoselection as a strategy for organ preservation in patients with T4 laryngeal squamous cell carcinoma with cartilage invasion. Laryngoscope 2009, 119:1510-1517.

8. Cohen EE, Karrison T, Kocherginsky M, Huang CH, Aguinik M, Mittal BB, Yunus F, Samant S, Brockstein B, Raez LE, Mehra R, Kumar P, Ondrey FG, Seiwert TY, Villaflor Meucci Vittoria, Haraf D, Vokes EE: DeCIDE: A phase III randomized trial of docetaxel (D), cisplatin (P), 5-fluorouracil (F) (TPF) induction chemotherapy (IC) in patients with N2/N3 locally advanced squamous cell carcinoma of the head and neck (SCCHN). J Clin Oncol (Meeting Abstracts) 2012:suppl; abstr 5500.

9. Haddad RI, Rabinowits G, Tishler RB, Adkins D, Khuri, Clark J, Lorch JH, Limaye S, Wirth LJ, O'Neill A, Riley S, Posner MR: The PARADIGM trial: A phase III study comparing sequential therapy (ST) to concurrent chemoradiotherapy (CRT) in locally advanced head and neck cancer (LAHNC): Preliminary toxicity report. J Clin Oncol (Meeting Abstracts) 2012: astr. 5501. 
10. Lefebvre $J$, Pointreau $Y$, Rolland F, Alfonsi M, Baudoux A, Sire C, Raucourt D de, Malard O, Degardin M, Tuchais C, Blot E, Rives M, Reyt E, Tourani JM, Geoffrois L, Peyrade F, Guichard F, Chevalier D, Babin E, Lang P, Janot F, Calais G, Garaud P, Bardet E: Induction chemotherapy followed by either chemoradiotherapy or bioradiotherapy for larynx preservation: the TREMPLIN randomized phase II study. J Clin Oncol 2013, 31:853-859.

11. Bonner JA, Harari PM, Giralt J, Cohen RB, Jones CU, Sur RK, Raben D, Baselga J, Spencer SA, Zhu J, Youssoufian H, Rowinsky EK, Ang KK: Radiotherapy plus cetuximab for locoregionally advanced head and neck cancer: 5 year survival data from a phase 3 randomised trial, and relation between cetuximab-induced rash and survival. Lancet Oncol 2010, 11:21-28.

12. Ang KK, Zhang QE, Rosenthal DI, Nguyen-Tan P, Sherman EJ, Weber RS, Galvin JM, Schwartz DL, El-Naggar AK, Gillison ML, Jordan R, List MA, Konski AA, Thorstad WL, Trotti A, Beitler JJ, Garden AS, Spanos WJ, Yom SS, Axelrod RS: A randomized phase III trial (RTOG 0522) of concurrent accelerated radiation plus cisplatin with or without cetuximab for stage III-IV head and neck squamous cell carcinomas (HNC). ASCO Meet Abstr 2011, 29:5500.

13. Chan JYK, Sanguineti G, Richmon JD, Marur S, Gourin CG, Koch W, Chung $\mathrm{CH}$, Quon $\mathrm{H}$, Bishop JA, Aygun N, Agrawal N: Retrospective review of positron emission tomography with contrast-enhanced computed tomography in the posttreatment setting in human papillomavirusassociated oropharyngeal carcinoma. Arch Otolaryngol Head Neck Surg 2012, 138:1040-1046.

14. Deasy JO, Moiseenko V, Marks L, Chao KSC, Nam J, Eisbruch A: Radiotherapy Dose-Volume effects on salivary gland function. Int J Radiat Oncol 2010 76(3, Supplement 1):S58-S63.

15. Mohan R, Wu Q, Manning M, Schmidt-Ullrich R: Radiobiological considerations in the design of fractionation strategies for intensity-modulated radiation therapy of head and neck cancers. Int J Radiat Oncol 2000, 46:619-630.

16. Eisbruch A, Foote RL, O'Sullivan B, Beitler JJ, Vikram B: Intensity-modulated radiation therapy for head and neck cancer: Emphasis on the selection and delineation of the targets. Semin Radiat Oncol 2002, 12:238-249.

17. Eisbruch A, Harris J, Garden AS, Chao CKS, Straube W, Harari PM, Sanguineti G, Jones CU, Bosch WR, Ang KK: Multi-Institutional trial of accelerated hypofractionated intensity-modulated radiation therapy for early-stage oropharyngeal cancer (RTOG 00-22). Int J Radiat Oncol 2010, 76:1333-1338.

18. Sanguineti G, Gunn GB, Endres EJ, Chaljub G, Cheruvu P, Parker B: Patterns of locoregional failure after exclusive IMRT for oropharyngeal carcinoma. Int J Radiat Oncol 2008, 72:737-746.

19. Eisbruch A: Intensity-modulated radiotherapy of head-and-neck cancer: encouraging early results. Int J Radiat Oncol 2002, 53:1-3.

20. Lee N, Harris J, Garden AS, Straube W, Glisson B, Xia P, Bosch W, Morrison WH Quivey J, Thorstad W, Jones C, Ang KK: Intensity-modulated radiation therapy with or without chemotherapy for nasopharyngeal carcinoma: Radiation Therapy Oncology Group phase II trial 0225. J Clin Oncol 2009, 27:3684-3690.

21. Montejo ME, Shrieve DC, Bentz BG, Hunt JP, Buchman LO, Agarwal N, Hitchcock YJ: IMRT with simultaneous integrated boost and concurrent chemotherapy for locoregionally advanced squamous cell carcinoma of the head and neck. Int J Radiat Oncol 2011, 81:e845-e852.

22. Morganti AG, Mignogna S, Deodato F, Massaccesi M, Cilla S, Calista F, Serafini G, Digesú C, Macchia G, Picardi V, Caravatta L, Di Lullo L, Giglio G, Sallustio G, Piermattei A, Cellini N, Valentini V: Feasibility study of moderately accelerated intensity-modulated radiotherapy plus concurrent weekly cisplatin after induction chemotherapy in locally advanced head-and neck cancer. Int J Radiat Oncol 2011, 79:1073-1080.

23. Bourhis J, Overgaard J, Audry H, Ang KK, Saunders M, Bernier J, Horiot J-C, Le Maître A, Pajak TF, Poulsen MG, O'Sullivan B, Dobrowsky W, Hliniak A, Skladowski K, Hay JH, Pinto LH, Fallai C, Fu KK, Sylvester R, Pignon J-P: Hyperfractionated or accelerated radiotherapy in head and neck cancer: a meta-analysis. Lancet 2006, 368:843-854.

24. Fu KK, Pajak TF, Trotti A, Jones CU, Spencer SA, Phillips TL, Garden AS, Ridge JA, Cooper JS, Ang KK: A radiation therapy oncology group (RTOG) phase III randomized study to compare hyperfractionation and two variants of accelerated fractionation to standard fractionation radiotherapy for head and neck squamous cell carcinomas: first report of RTOG 9003. Int J Radiat Oncol 2000, 48:7-16.

25. Overgaard J, Hansen HS, Specht L, Overgaard M, Grau C, Andersen E, Bentzen J, Bastholt L, Hansen O, Johansen J, Andersen L, Evensen JF: Five compared with six fractions per week of conventional radiotherapy of squamous-cell carcinoma of head and neck: DAHANCA $6 \& 7$ randomised controlled trial. Lancet 2003, 362:933-940.
26. Ang K, Pajak T, Wheeler R, Rosenthal D, Nguyen-Tan F, Lu C, Kim H, Axelrod R, Silverman C, Weber R: A phase III trial to test accelerated versus standard fractionation in combination with concurrent cisplatin for head and neck carcinomas (RTOG 0129): report of efficacy and toxicity. Int J Radiat Oncol 2010, 77:1-2.

27. Bourhis J, Sire C, Graff $P$, Grégoire V, Maingon P, Calais G, Gery B, Martin L, Alfonsi M, Desprez P, Pignon T, Bardet E, Rives M, Geoffrois L, Daly-Schveitzer N, Sen S, Tuchais C, Dupuis O, Guerif S, Lapeyre M, Favrel V, Hamoir M, Lusinchi A, Temam S, Pinna A, Tao YG, Blanchard P, Aupérin A: Concomitant chemoradiotherapy versus acceleration of radiotherapy with or without concomitant chemotherapy in locally advanced head and neck carcinoma (GORTEC 99-02): an open-label phase 3 randomised trial. Lancet Oncol 2012, 13:145-153.

28. Hui EP, Ma BB, Leung SF, King AD, Mo F, Kam MK, Yu BK, Chiu SK, Kwan WH, Ho R, Chan I, Ahuja AT, Zee BC, Chan AT: Randomized phase ii trial of concurrent cisplatin-radiotherapy with or without neoadjuvant docetaxel and cisplatin in advanced nasopharyngeal carcinoma. J Clin Oncol 2009, 27:242-249.

29. Salama JK, Haddad RI, Kies MS, Busse PM, Dong L, Brizel DM, Eisbruch A, Tishler RB, Trotti AM, Garden AS: Clinical practice guidance for radiotherapy planning after induction chemotherapy in locoregionally advanced head-and-neck cancer. Int J Radiat Oncol 2009, 75:725-733.

30. Ang KK, Trotti A, Brown BW, Garden AS, Foote RL, Morrison WH, Geara FB, Klotch DW, Goepfert H, Peters LJ: Randomized trial addressing risk features and time factors of surgery plus radiotherapy in advanced head-and-neck cancer. Int J Radiat Oncol Biol Phys 2001, 51:571-578.

31. Sanguineti G, Richetti A, Bignardi M, Corvo' R, Gabriele P, Sormani MP, Antognoni P: Accelerated versus conventional fractionated postoperative radiotherapy for advanced head and neck cancer: results of a multicenter Phase III study. Int J Radiat Oncol Biol Phys 2005, 61:762-771.

32. Shintani SA, Foote RL, Lowe VJ, Brown PD, Garces Yl, Kasperbauer JL: Utility of PET/CT imaging performed early after surgical resection in the adjuvant treatment planning for head and neck cancer. Int J Radiat Oncol 2008, 70:322-329.

33. Lo EJ, Bell D, Woo JS, Li G, Hanna EY, El-Naggar AK, Sturgis EM: Human papillomavirus and WHO type I nasopharyngeal carcinoma. Laryngoscope 2010, 120:1990-1997.

34. Neubauer E, Dong L, Followill DS, Garden AS, Court LE, White RA, Kry SF: Assessment of shoulder position variation and its impact on IMRT and VMAT doses for head and neck cancer. Radiat Oncol 2012, 7:19.

35. ICRU: Prescribing, Recording and Reporting Photon Beam Therapy. Report 50. Washington, DC: International Commission on Radiation Units and Measurements; 1993

36. ICRU: Prescribing, Recording, and Reporting Photon-Beam IntensityModulated Radiation Therapy (IMRT): Contents. Oxford University Press. J ICRU 2010, 10:NP

37. Ling CC, Humm J, Larson S, Amols H, Fuks Z, Leibel S, Koutcher JA: Towards multidimensional radiotherapy (MD-CRT): biological imaging and biological conformality. Int J Radiat Oncol 2000, 47:551-560.

38. ICRU: 4. Definition of Volumes - JOURNAL OF THE ICRU. In ICRU Rep 83. Volume 10. Oxford: Oxford University Press; 2010.

39. Geets X, Daisne J-F, Tomsej M, Duprez T, Lonneux M, Grégoire V: Impact of the type of imaging modality on target volumes delineation and dose distribution in pharyngo-laryngeal squamous cell carcinoma: comparison between pre- and per-treatment studies. Radiother Oncol 2006, 78:291-297.

40. Geets X, Tomsej M, Lee JA, Duprez T, Coche E, Cosnard G, Lonneux M Grégoire V: Adaptive biological image-guided IMRT with anatomic and functional imaging in pharyngo-laryngeal tumors: Impact on target volume delineation and dose distribution using helical tomotherapy. Radiother Oncol 2007, 85:105-115.

41. Chao KSC, Wippold FJ II, Ozyigit G, Tran BN, Dempsey JF: Determination and delineation of nodal target volumes for head-and-neck cancer based on patterns of failure in patients receiving definitive and postoperative IMRT. Int J Radiat Oncol 2002, 53:1174-1184.

42. Wambersie A, Landgerg T: ICRU Report 62: Prescribing, Recording and Reporting Photon Beam Therapy. ICRU Pub/ Bethesda MD 1999.

43. Berthelsen AK, Dobbs J, Kjellén E, Landberg T, Möller TR, Nilsson P, Specht L, Wambersie A: What's new in target volume definition for radiologists in ICRU Report 71? How can the ICRU volume definitions be integrated in clinical practice? Cancer Imaging Off Publ Int Cancer Imaging Soc 2007, 7:104-116. 
44. Hu KS, Quon H, Harrison L: Management of the Neck: Radiation Therapy and Chemotherapy. In Head Neck Cancer Multidiscip Approach. 3rd edition. Philadelphia: Lippincott Williams \& Wilkins; 2009:204-231.

45. Grégoire V, Coche $\mathrm{E}$, Cosnard G, Hamoir M, Reychler H: Selection and delineation of lymph node target volumes in head and neck conformal radiotherapy. Proposal for standardizing terminology and procedure based on the surgical experience. Radiother Oncol 2000, 56:135-150.

46. Grégoire V, Levendag P, Ang KK, Bernier J, Braaksma M, Budach V, Chao C, Coche E, Cooper JS, Cosnard G, Eisbruch A, El-Sayed S, Emami B, Grau C, Hamoir M, Lee N, Maingon P, Muller K, Reychler H: CT-based delineation of lymph node levels and related CTVs in the node-negative neck: DAHANCA, EORTC, GORTEC, NCIC, RTOG consensus guidelines. Radiother Oncol 2003, 69:227-236.

47. Grégoire V, Eisbruch A, Hamoir M, Levendag P: Proposal for the delineation of the nodal CTV in the node-positive and the postoperative neck. Radiother Oncol 2006, 79:15-20.

48. Ben David, Merav, Eisbruch, Avraham: Delineating neck targets for intensitymodulated radiation therapy of head and neck cancer what have we learned from marginal recurrences?. In IMRT IGRT SBRT Adv Treat Plan Deliv Radiother. Edited by Meyer J. Basel: Karger Publishers; 2007:193-207.

49. Chen AM, Farwell DG, Luu Q, Donald PJ, Perks J, Purdy JA: Evaluation of the planning target volume in the treatment of head and neck cancer with intensity-modulated radiotherapy: what is the appropriate expansion margin in the setting of daily image guidance? Int J Radiat Oncol Biol Phys 2011, 81:943-949.

50. Eisbruch A, Gregoire V: Balancing risk and reward in target delineation for highly conformal radiotherapy in head and neck cancer. Semin Radiat Oncol 2009, 19:43-52.

51. Rao NG, Sanguineti G, Chaljub G, Newlands SD, Qiu S: Do neck levels negative on initial CT need to be dissected after definitive radiation therapy with or without chemotherapy? Head Neck 2008, 30:1090-1098.

52. Van den Brekel MW, Stel HV, Castelijns JA, Nauta JJ, van der Waal I, Valk J, Meyer CJ, Snow GB: Cervical lymph node metastasis: assessment of radiologic criteria. Radiology 1990, 177:379-384.

53. Apisarnthanarax S, Elliott DD, El-Naggar AK, Asper JA, Blanco A, Ang KK, Garden AS, Morrison WH, Rosenthal D, Weber RS, Chao KSC: Determining optimal clinical target volume margins in head-and-neck cancer based on microscopic extracapsular extension of metastatic neck nodes. Int J Radiat Oncol 2006, 64:678-683.

54. Yao M, Nguyen T, Buatti JM, Dornfeld KJ, Tan H, Wacha J, Bayouth JE, Clamon GH, Funk GF, Smith RB, Chang K, Hoffman HT: Changing failure patterns in oropharyngeal squamous cell carcinoma treated with intensity modulated radiotherapy and implications for future research. Am J Clin Oncol 2006, 29:606-612.

55. Weiss MH, Harrison LB, Isaacs R: USe of decision analysis in planning a management strategy for the stage no neck. Arch Otolaryngol Neck Surg 1994, 120:699-702.

56. Lapeyre M, Toledano I, Bourry N, Bailly C, Cachin F: Délinéation des volumes cibles des cancers des voies aérodigestives supérieures en radiothérapie conformationnelle avec modulation d'intensité. Cancer/ Radiothérapie 2011, 15:466-472.

57. Vorwerk H, Hess CF: Guidelines for delineation of lymphatic clinical target volumes for high conformal radiotherapy: head and neck region. Radiat Oncol 2011, 6:1-25.

58. Augurio A, Pilla AD, Tartaro A: Head and Neck Lymph Nodes. In A Guide for Delineation of Lymph Nodal Clinical Target Volume in Radiation Therapy. Edited by Ausili Cèfaro G, Genovesi D, Perez CA, Vinciguerra A. Springer Berlin Heidelberg; 2008:63-95.

59. Sanguineti G, Culp LR, Endres EJ, Bayouth JE: Are neck nodal volumes drawn on $\mathrm{CT}$ slices covered by standard three-field technique? Int Radiat Oncol 2004, 59:725-742.

60. Hall WH, Guiou M, Lee NY, Dublin A, Narayan S, Vijayakumar S, Purdy JA, Chen AM: Development and validation of a standardized method for contouring the brachial plexus: preliminary dosimetric analysis among patients treated with IMRT for head-and-neck cancer. Int J Radiat Oncol Biol Phys 2008, 72:1362-1367

61. Sanguineti G, Adapala P, Endres EJ, Brack C, Fiorino C, Sormani MP, Parker B: Dosimetric Predictors of Laryngeal Edema. Int J Radiat Oncol 2007, 68:741-749.

62. Lee N, Mechalakos J, Puri DR, Hunt M: Choosing an intensity-modulated radiation therapy technique in the treatment of head-and-neck cancer. Int J Radiat Oncol Biol Phys 2007, 68:1299-1309.
63. Takamiya R, Missett B, Weinberg V, Akazawa C, Akazawa P, Zytkovicz A, Bucci MK, Lee N, Quivey JM, Xia P: Simplifying intensity-modulated radiotherapy plans with fewer beam angles for the treatment of oropharyngeal carcinoma. J Appl Clin Med Phys Am Coll Med Phys 2007, 8:26-36.

64. Yao M, Dornfeld KJ, Buatti JM, Skwarchuk M, Tan H, Nguyen T, Wacha J, Bayouth JE, Funk GF, Smith RB, Graham SM, Chang K, Hoffman HT: Intensity-modulated radiation treatment for head-and-neck squamous cell carcinoma-the University of lowa experience. Int J Radiat Oncol Biol Phys 2005, 63:410-421.

65. Dabaja B, Salehpour MR, Rosen I, Tung S, Morrison WH, Ang KK, Garden AS: Intensity-modulated radiation therapy (IMRT) of cancers of the head and neck: comparison of split-field and whole-field techniques. Int J Radiat Oncol Biol Phys 2005, 63:1000-1005

66. Fiorino C, Dell'OCa I, Pierelli A, Broggi S, Martin ED, Muzio ND, Longobardi B, Fazio F, Calandrino R: Significant improvement in normal tissue sparing and target coverage for head and neck cancer by means of helical tomotherapy. Radiother Oncol 2006, 78:276-282.

67. Clemente S, Wu B, Sanguineti G, Fusco V, Ricchetti F, Wong J, McNutt T: SmartArc-based volumetric modulated Arc therapy for oropharyngeal cancer: a dosimetric comparison with both intensity-modulated radiation therapy and helical tomotherapy. Int J Radiat Oncol 2011 80:1248-1255

68. Trotti A, Bellm LA, Epstein JB, Frame D, Fuchs HJ, Gwede CK, Komaroff E, Nalysnyk L, Zilberberg MD: Mucositis incidence, severity and associated outcomes in patients with head and neck cancer receiving radiotherapy with or without chemotherapy: a systematic literature review. Radiother Oncol J Eur Soc Ther Radiol Oncol 2003, 66:253-262.

69. Sanguineti G, Ricchetti F, Wu B, Agrawal N, Gourin C, Agbahiwe H, Marur S, Clemente S, McNutt T, Forastiere A: Volumetric change of human papillomavirus-related neck lymph nodes before, during, and shortly after intensity-modulated radiation therapy. Head Neck 2012, 34:1640-1647.

70. Hansen EK, Bucci MK, Quivey JM, Weinberg V, Xia P: Repeat CT imaging and replanning during the course of IMRT for head-and-neck cancer. Int J Radiat Oncol 2006, 64:355-362.

71. Ricchetti F, Wu B, McNutt T, Wong J, Forastiere A, Marur S, Starmer H, Sanguineti G: Volumetric change of selected organs at risk during IMRT for oropharyngeal cancer. Int J Radiat Oncol 2011, 80:161-168.

72. Koyfman SA, Adelstein DJ: Enteral feeding tubes in patients undergoing definitive chemoradiation therapy for head-and-neck cancer: a critical review. Int J Radiat Oncol 2012, 84:581-589.

73. Li H, Zhu XR, Zhang L, Dong L, Tung S, Ahamad A, Chao KSC, Morrison WH, Rosenthal DI, Schwartz DL, Mohan R, Garden AS: Comparison of 2D radiographic images and $3 \mathrm{D}$ cone beam computed tomography for positioning head-and-neck radiotherapy patients. Int J Radiat Oncol Biol Phys 2008, 71:916-925.

74. Kim Y, Tomé WA, Bal M, McNutt TR, Spies L: The impact of dental metal artifacts on head and neck IMRT dose distributions. Radiother Oncol J Eur Soc Ther Radiol Oncol 2006, 79:198-202.

75. Yang C, Liu T, Jennelle RL, Ryu JK, Vijayakumar S, Purdy JA, Chen AM: Utility of megavoltage Fan-beam CT for treatment planning in a head-and-neck cancer patient with extensive dental fillings undergoing helical tomotherapy. Med Dosim 2010, 35:108-114.

76. Jeraj $R$, Keall $P$ : The effect of statistical uncertainty on inverse treatment planning based on Monte Carlo dose calculation. Phys Med Biol 2000, 45:3601

77. Nutting CM, Morden JP, Harrington KJ, Urbano TG, Bhide SA, Clark C, Miles EA, Miah AB, Newbold K, Tanay M, Adab F, Jefferies SJ, Scrase C, Yap BK, A'Hern RP, Sydenham MA, Emson M, Hall E: Parotid-sparing intensity modulated versus conventional radiotherapy in head and neck cancer (PARSPORT): a phase 3 multicentre randomised controlled trial. Lancet Oncol 2011, 12:127-136.

78. Peters $\sqcup$, Goepfert $H$, Ang KK, Byers RM, Maor MH, Guillamondegui O, Morrison WH, Weber RS, Garden AS, Frankenthaler RA: Evaluation of the dose for postoperative radiation therapy of head and neck cancer: First

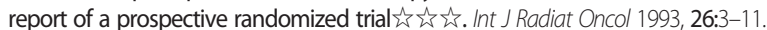

79. Bernier J, Domenge C, Ozsahin M, Matuszewska K, Lefèbvre J-L, Greiner RH, Giralt J, Maingon P, Rolland F, Bolla M, Cognetti F, Bourhis J, Kirkpatrick A, van Glabbeke M: Postoperative irradiation with or without concomitant chemotherapy for locally advanced head and neck cancer. N Engl J Med 2004, 350:1945-1952. 
80. Tandon S, Munir N, Roland NJ, Lancaster J, Jackson SR, Jones TM: A systematic review and Number Needed to Treat analysis to guide the management of the neck in patients with squamous cell carcinoma of the head and neck. Auris Nasus Larynx 2011, 38:702-709.

81. Marks LB, Yorke ED, Jackson A, Ten Haken RK, Constine LS, Eisbruch A, Bentzen SM, Nam J, Deasy JO: Use of normal tissue complication probability models in the clinic. Int J Radiat Oncol 2010, 76(3, Supplement 1):S10-S19.

82. Yao M, Chang K, Funk GF, Lu H, Tan H, Wacha J, Dornfeld KJ, Buatti JM: The failure patterns of oral cavity squamous cell carcinoma after intensity-modulated radiotherapy-the university of iowa experience. Int J Radiat Oncol Biol Phys 2007, 67:1332-1341.

83. Daly ME, Le Q-T, Kozak MM, Maxim PG, Murphy JD, Hsu A, Loo BW, Kaplan MJ, Fischbein NJ, Chang DT: Intensity-modulated radiotherapy for oral cavity squamous cell carcinoma: patterns of failure and predictors of local control. Int J Radiat Oncol 2011, 80:1412-1422.

84. Scholl P, Byers RM, Batsakis JG, Wolf P, Santini H: Microscopic cut-through of cancer in the surgical treatment of squamous carcinoma of the tongue. Am J Surg 1986, 152:354-360.

85. Vergeer MR, Doornaert PAH, Jonkman A, Kaanders JHAM, van den Ende PLA, de Jong MA, Leemans CR, Slotman BJ, Langendijk JA: Ipsilateral irradiation for oral and oropharyngeal carcinoma treated with primary surgery and postoperative radiotherapy. Int J Radiat Oncol Biol Phys 2010 78:682-688.

86. Werner JA, Dünne AA, Myers JN: Functional anatomy of the lymphatic drainage system of the upper aerodigestive tract and its role in metastasis of squamous cell carcinoma. Head Neck 2003, 25:322-332.

87. Byers RM, Weber RS, Andrews T, McGill D, Kare R, Wolf P: Frequency and therapeutic implications of "skip metastases" in the neck from squamous carcinoma of the oral tongue. Head Neck 1997, 19:14-19.

88. Chao CKS, Perez CA, Brady LW: Oral Cavity. In Radiat Oncol Manag Decis. 3rd edition. Philadelphia: LWW; 2011:247-258.

89. Hansen EK, Yom SS, Chen CP, Schechter NR: Cancer of the lip and Oral Cavity. In Handb Evid-Based Radiat Oncol. 2nd ed. 2010th edition. Edited by Hansen E, III MR. New York: Springer; 2010:131-144.

90. Larsen SR, Johansen J, Sørensen JA, Krogdahl A: The prognostic significance of histological features in oral squamous cell carcinoma. J Oral Pathol Med Off Publ Int Assoc Oral Pathol Am Acad Oral Pathol 2009, 38:657-662.

91. Yuen AP, Lam KY, Wei WI, Lam KY, Ho CM, Chow TL, Yuen WF: A comparison of the prognostic significance of tumor diameter, length, width, thickness, area, volume, and clinicopathological features of oral tongue carcinoma. Am J Surg 2000, 180:139-143.

92. Cole I, Hughes $L$ : The relationship of cervical lymph node metastases to primary sites of carcinoma of the upper aerodigestive tract: a pathological study. Aust N Z J Surg 1997, 67:860-865.

93. Shah JP, Candela FC, Poddar AK: The patterns of cervical lymph node metastases from squamous carcinoma of the oral cavity. Cancer 1990, 66:109-113.

94. Rasch C, Keus R, Pameijer FA, Koops W, de Ru V, Muller S, Touw A, Bartelink $\mathrm{H}$, van Herk M, Lebesque JV: The potential impact of CT-MRI matching on tumor volume delineation in advanced head and neck cancer. Int $\mathrm{J}$ Radiat Oncol 1997, 39:841-848.

95. Sham JS, Cheung YK, Choy D, Chan FL, Leong L: Nasopharyngeal carcinoma: CT evaluation of patterns of tumor spread. AJNR Am J Neuroradiol 1991, 12:265-270

96. Orlandi E, Tomatis S, Potepan P, Bossi P, Mongioj V, Carrara M, Palazzi M, Franceschini M, Bergamini C, Locati L, lannacone E, Guzzo M, Ibba T, Crippa F, Licitra L, Pignoli E, Fallai C: Critical analysis of locoregional failures following intensity-modulated radiotherapy for nasopharyngeal carcinoma. Future Oncol Lond Engl 2013, 9:103-114.

97. Sham J, Choy D, Kwong PW, Cheng AC, Kwong DL, Yau CC, Wan KY, Au GK: Radiotherapy for nasopharyngeal carcinoma: shielding the pituitary may improve therapeutic ratio. Int J Radiat Oncol Biol Phys 1994, 29:699-704.

98. Shanmugaratnam KS, Sobin LH: Histological typing of upper respiratory tract tumors Geneva. 1978

99. Chan J, Bray F, McCarron P: Nasopharyngeal carcinoma. In Pathology and genetics of head and neck tumours. World Health Organization classification of tumours. Edited by Barnes L, Eveson JW, Reichart PA, Sidransky D. Lyon, France: IARC Press; 2005:85-97.

100. Tse LA, Yu IT-S, Mang OW-K, Wong S-L: Incidence rate trends of histological subtypes of nasopharyngeal carcinoma in Hong Kong. Br J Cancer 2006, 95:1269-1273.
101. Pathmanathan R, Prasad U, Chandrika G, Sadler R, Flynn K, Raab-Traub N: Undifferentiated, nonkeratinizing, and squamous cell carcinoma of the nasopharynx. Variants of Epstein-Barr virus-infected neoplasia. Am J Pathol 1995, 146:1355-1367.

102. Ruckenstein MJ: Nasopharyngeal Carcinoma. In Compr Rev Otolaryngol. Philadelphia: W.B. Saunders; 2004:197-198.

103. Lee JT, Ko CY: Has survival improved for nasopharyngeal carcinoma in the United States? Otolaryngol-Head Neck Surg Off J Am Acad OtolaryngolHead Neck Surg 2005, 132:303-308.

104. Reddy SP, Raslan WF, Gooneratne S, Kathuria S, Marks JE: Prognostic significance of keratinization in nasopharyngeal carcinoma. Am J Otolaryngol 1995, 16:103-108.

105. Kim K, Wu H-G, Kim HJ, Sung M-W, Kim KH, Lee S-H, Heo DS, Kim HJ, Park C: Intensity-modulated radiation therapy with simultaneous integrated boost technique following neoadjuvant chemotherapy for locoregionally advanced nasopharyngeal carcinoma. Head Neck 2009, 31:1121-1128.

106. Peponi E, Glanzmann C, Kunz G, Renner C, Tomuschat K, Studer G: Simultaneous integrated boost intensity-modulated radiotherapy (SIB-IMRT) in nasopharyngeal cancer. Strahlenther Onkol 2010, 186:135-142.

107. Dubrulle F, Souillard R, Hermans R: Extension patterns of nasopharyngeal carcinoma. Eur Radiol 2007, 17:2622-2630.

108. King AD, Lam WW, Leung SF, Chan YL, Teo P, Metreweli C: MRI of local disease in nasopharyngeal carcinoma: tumour extent vs tumour stage. Br J Radiol 1999, 72:734-741.

109. Kong L, Zhang Y-W, Hu C-S, Guo Y: Neoadjuvant chemotherapy followed by concurrent chemoradiation for locally advanced nasopharyngeal carcinoma. Chin J Cancer 2010, 29:551-555.

110. Hunt MA, Zelefsky MJ, Wolden S, Chui C-S, LoSasso T, Rosenzweig K, Chong L, Spirou SV, Fromme L, Lumley M, Amols HA, Ling CC, Leibel SA: Treatment planning and delivery of intensity-modulated radiation therapy for primary nasopharynx cancer. Int J Radiat Oncol 2001, 49:623-632.

111. Lo SS, Lu JJ: Natural History, Presenting Symptoms, and Diagnosis of Nasopharyngeal Carcinoma. In Nasopharyngeal Cancer. Edited by Lu JJ, Cooper JS, Lee AWM. Berlin Heidelberg: Springer Berlin Heidelberg; 2010:41-51. [Medical Radiology]

112. Pan W-R, Suami H, Corlett RJ, Ashton MW: Lymphatic drainage of the nasa fossae and nasopharynx: preliminary anatomical and radiological study with clinical implications. Head Neck 2009, 31:52-57.

113. Wang X, Li L, Hu C, Zhou Z, Ying H, Ding J, Feng Y: Patterns of level II node metastasis in nasopharyngeal carcinoma. Radiother Oncol 2008, 89:28-32.

114. Mukherji SK, Armao D, Joshi VM: Cervical nodal metastases in squamous cell carcinoma of the head and neck: What to expect. Head Neck 2001, 23:995-1005.

115. Ho FC, Tham IW, Earnest A, Lee K, Lu JJ: Patterns of regional lymph node metastasis of nasopharyngeal carcinoma: A meta-analysis of clinical evidence. BMC Cancer 2012, 12:98.

116. Wang XS, Hu CS, Ying HM, Zhou ZR, Ding JH, Feng Y: Patterns of Retropharyngeal Node Metastasis in Nasopharyngeal Carcinoma. Int J Radiat Oncol 2009, 73:194-201.

117. Lee AW, Sham JS, Poon YF, Ho JH: Treatment of stage I nasopharyngeal carcinoma: analysis of the patterns of relapse and the results of withholding elective neck irradiation. Int J Radiat Oncol Biol Phys 1989, 17:1183-1190

118. Sanghera P, McConkey C, Ho K-F, Glaholm J, Hartley A: Hypofractionated accelerated radiotherapy with concurrent chemotherapy for locally advanced squamous cell carcinoma of the head and neck. Int J Radiat Oncol Biol Phys 2007, 67:1342-1351.

119. Sanguineti G, Califano J, Stafford E, Fox J, Koch W, Tufano R, Sormani MP, Forastiere A: Defining the risk of involvement for each neck nodal level in patients with early t-stage node-positive oropharyngeal carcinoma. Int J Radiat Oncol 2009, 74:1356-1364.

120. Randomized phase III trial comparing induction chemotherapy followed by radiotherapy to concomitant chemoradiotherapy for laryngeal preservation in T3M0 pyriform sinus carcinoma [http://informahealthcare.com.bvs.cilea.it/ doi/abs/10.3109/00016480902914080]

121. Studer G, Peponi E, Kloeck S, Dossenbach T, Huber G, Glanzmann C: Surviving hypopharynx-larynx carcinoma in the era of IMRT. Int J Radiat Oncol 2010, 77:1391-1396.

122. Lee NY, O'Meara W, Chan K, Della-Bianca C, Mechalakos JG, Zhung J, Wolden SL, Narayana A, Kraus D, Shah JP, Pfister DG: Concurrent chemotherapy and intensity-modulated radiotherapy for locoregionally advanced laryngeal and hypopharyngeal cancers. Int J Radiat Oncol Biol Phys 2007, 69:459-468. 
123. Miah AB, Bhide SA, Guerrero-Urbano MT, Clark C, Bidmead AM, St. Rose $S$, Barbachano Y, A'Hern R, Tanay M, Hickey J, Nicol R, Newbold KL, Harrington $\mathrm{K}$, Nutting CM: Dose-escalated intensity-modulated radiotherapy is feasible and May improve locoregional control and laryngeal preservation in laryngo-hypopharyngeal cancers. Int J Radiat Oncol 2012, 82:539-547.

124. Nakamura K, Shioyama Y, Sasaki T, Ohga S, Saku M, Urashima Y, Yoshitake T, Nakashima T, Kuratomi Y, Komune S, Terashima H, Honda H: Chemoradiation therapy with or without salvage surgery for early squamous cell carcinoma of the hypopharynx. Int J Radiat Oncol 2005, 62:680-683.

125. Okamoto M, Takahashi H, Yao K, Inagi K, Nakayama M, Nagai H: Clinical impact of using chemoradiotherapy as a primary treatment for hypopharyngeal cancer. Acta Oto-Laryngol Suppl 2002, 547:11-14.

126. Lefebvre J-L, Chevalier D, Luboinski B, Kirkpatrick A, Collette L, Sahmoud T: Larynx preservation in pyriform sinus cancer: preliminary results of a European organization for research and treatment of cancer phase III trial. JNCI J Natl Cancer Inst 1996, 88:890.

127. Lefebvre JL, Rolland F, Tesselaar M, Bardet E, Leemans CR, Geoffrois L, Hupperets P, Barzan L, de Raucourt D, Chevalier D, Licitra L, Lunghi F, Stupp R, Lacombe D, Bogaerts J, Horiot JC, Bernier J, Vermorken JB, for the EORTC Head and Neck Cancer Cooperative Group and the EORTC Radiation Oncology Group: Phase 3 Randomized Trial on Larynx Preservation Comparing Sequential vs Alternating Chemotherapy and Radiotherapy. J Natl Cancer Inst 2009, 101:142-152.

128. Gupta GP, Lee NY: Hypopharyngeal Carcinoma. In Target Vol Delin Field Setup. Edited by Lee NY, Lu JJ. Berlin Heidelberg: Springer; 2013:29-34.

129. Lapeyre M, Bailly C, Toledano I, Montalban A, Russier M: Cancer de I'hypopharynx et du larynx: proposition de sélection et délimitation des volumes cibles microscopiques péri-tumoraux (aires ganglionnaires exclues). Cancer/RadiothÃ@rapie 2010, 14(Supplement 1):S43-S51.

130. Amatsu M, Mohri M, Kinishi M: Significance of retropharyngeal node dissection at radical surgery for carcinoma of the hypopharynx and cervical esophagus. Laryngoscope 2001, 111:1099-1103.

131. Laskar SG, Baijal G, Murthy V, Chilukuri S, Budrukkar A, Gupta T, Agarwal JP: Hypofractionated radiotherapy for T1N0M0 glottic cancer: retrospective analysis of Two different cohorts of dose-fractionation schedules from a single institution. Clin Oncol 2012, 24:e180-e186.

132. Yamazaki H, Nishiyama K, Tanaka E, Koizumi M, Chatani M: Radiotherapy for early glottic carcinoma (T1NOM0): results of prospective randomized study of radiation fraction size and overall treatment time. Int J Radia Oncol Biol Phys 2006, 64:77-82.

133. Trotti A, Pajak T, Emami B, Hammond E, Jones C, Morrison W, Sagar S, Ridge J, Fu KK, Ang K: A randomized trial of hyperfractionation versus standard fractionation in T2 squamous cell carcinoma of the vocal cord. Int $J$ Radiat Oncol 2006, 66:S15.

134. Baujat B, Bourhis J, Blanchard P, Overgaard J, Ang KK, Saunders M, Le Maître A, Bernier J, Horiot JC, Maillard E, Pajak TF, Poulsen MG, Bourredjem A, O'Sullivan B, Dobrowsky W, Andrzej H, Skladowski K, Hay JH, Pinto LH, Fu KK, Fallai C, Sylvester R, Pignon JP, MARCH Collaborative Group: Hyperfractionated or Accelerated Radiotherapy for Head and Neck Cancer. Volume 12 Art. No.: CD002026. DOl: 10.1002/14651858.CD002026.pub2. John Wiley \& Sons, Ltd; 2010. http://onlinelibrary.wiley.com/enhanced/doi/ 10.1002/14651858.CD002026.pub2. Accessed 7 Jan 2015.

135. Russi EG, Sanguineti G, Chiesa F, Franco P, Succo G, Merlotti A, Ansarin M, Melano A, Alterio D, Pergolizzi S, Buglione M, Reali A, Ricardi U, Corvò R: Is there a role for postoperative radiotherapy following open partial laryngectomy when prognostic factors on the pathological specimen are unfavourable? A survey of head and neck surgical/radiation oncologists. Acta Otorhinolaryngol Ital Organo Uff Della Soc Ital Otorinolaringol E Chir Cerv-facc 2013, 33:311-319.

136. Spriano G, Antognoni P, Sanguineti G, Sormani M, Richetti A, Ameli F, Piantanida R, Luraghi R, Magli A, Corvo R, Tordiglione M, Vitale V: Laryngeal long-term morbidity after supraglottic laryngectomy and postoperative radiation therapy. Am J Otolaryngol 2000, 21:14-21.

137. Chao CKS, Apisarnthanarax S, Ozyigit G: Practical Essentials of Intensity Modulated Radiation Therapy. 2nd edition. Philadelphia: Lippincott Williams \& Wilkins; 2005.

138. Hansen EK, Roach M: Handbook of Evidence-Based Radiation Oncology. 2nd ed. New York Heidelberg Dordrecht London: Springer; 2010.

139. Kutta H, Steven P, Paulsen F: Anatomical definition of the subglottic region. Cells Tissues Organs 2006, 184:205-214.
140. Eisbruch A: Commentary: induction chemotherapy for head and neck cancer: hypothesis-based rather than evidence-based medicine. Oncologist 2007, 12:975-977.

141. Chera BS, Amdur RJ, Morris CG, Mendenhall WM: Carotid-sparing intensitymodulated radiotherapy for early-stage squamous cell carcinoma of the true vocal cord. Int J Radiat Oncol Biol Phys 2010, 77:1380-1385.

142. Rosenthal DI, Fuller CD, Barker JL Jr, Mason B, Garcia JA, Lewin JS, Holsinger FC, Stasney CR, Frank SJ, Schwartz DL, Morrison WH, Garden AS, Ang KK: Simple carotid-sparing intensity-modulated radiotherapy technique and preliminary experience for T1-2 glottic cancer. Int J Radiat Oncol 2010, 77:455-461

143. Van den Bogaert W, Ostyn F, van der Schueren E: The different clinical presentation, behaviour and prognosis of carcinomas originating in the epilarynx and the lower supraglottis. Radiother Oncol J Eur Soc Ther Radiol Oncol 1983, 1:117-131.

144. Lengelé $B$, Hamoir $M$, Scalliet $P$, Grégoire V: Anatomical bases for the radiological delineation of lymph node areas. Major collecting trunks, head and neck. Radiother Oncol J Eur Soc Ther Radiol Oncol 2007, 85:146-155.

145. De Bree R, Leemans CR, Silver CE, Robbins KT, Rodrigo JP, Rinaldo A, Takes RP, Shaha AR, Medina JE, Suárez C, Ferlito A: Paratracheal lymph node dissection in cancer of the larynx, hypopharynx, and cervical esophagus: The need for guidelines. Head Neck 2011, 33:912-916.

146. Daly ME, Chen AM, Bucci MK, El-Sayed I, Xia P, Kaplan MJ, Eisele DW: Intensity-modulated radiation therapy for malignancies of the nasal cavity and paranasal sinuses. Int J Radiat Oncol 2007, 67:151-157.

147. Wiegner EA, Daly ME, Murphy JD, Abelson J, Chapman CH, Chung M, Yu Y, Colevas AD, Kaplan MJ, Fischbein N, Le Q-T, Chang DT: Intensity-modulated radiotherapy for tumors of the nasal cavity and paranasal sinuses: clinical outcomes and patterns of failure. Int J Radiat Oncol 2012, 83:243-251.

148. Hoppe BS, Wolden SL, Zelefsky MJ, Mechalakos JG, Shah JP, Kraus DH, Lee $\mathrm{N}$ : Postoperative intensity-modulated radiation therapy for cancers of the paranasal sinuses, nasal cavity, and lacrimal glands: Technique, early outcomes, and toxicity. Head Neck 2008, 30:925-932.

149. Spratt D, Cabanillas R, Lee NY: The Paranasal Sinuses. In Target Vol Delin Field Setup. Edited by Lee NY, Lu JJ. Berlin Heidelberg: Springer; 2013:45-48.

150. Zanation AM, Ferlito A, Rinaldo A, Gore MR, Lund VJ, McKinney KA, Suárez C, Takes RP, Devaiah AK: When, how and why to treat the neck in patients with esthesioneuroblastoma: a review. Eur Arch Otorhinolaryngol 2010, 267:1667-1671.

151. Jiang GL, Ang KK, Peters $\sqcup$, Wendt CD, Oswald MJ, Goepfert H: Maxillary sinus carcinomas: natural history and results of postoperative radiotherapy. Radiother Oncol 1991, 21:193-200.

152. Le Q-T, Fu KK, Kaplan MJ, Terris DJ, Fee WE, Goffinet DR: Lymph node metastasis in maxillary sinus carcinoma. Int J Radiat Oncol 2000, 46:541-549.

153. Fukumitsu N, Okumura T, Mizumoto M, Oshiro Y, Hashimoto T, Kanemoto A, Hashii H, Ohkawa A, Moritake T, Tsuboi K, Tabuchi K, Wada T, Hara A, Sakurai H: Outcome of T4 (International Union Against Cancer Staging System, 7th edition) or Recurrent Nasal Cavity and Paranasal Sinus Carcinoma Treated with Proton Beam. Int J Radiat Oncol 2011, 83:704-711.

154. Zenda S, Kohno R, Kawashima M, Arahira S, Nishio T, Tahara M, Hayashi R, Kishimoto S, Ogino T: Proton beam therapy for unresectable malignancies of the nasal cavity and paranasal sinuses. Int J Radiat Oncol 2011, 81:1473-1478.

155. Garden AS, El-Naggar AK, Morrison WH, Callender DL, Ang KK, Peters LJ: Postoperative radiotherapy for malignant tumors of the parotid gland. Int J Radiat Oncol 1997, 37:79-85.

156. Terhaard CHJ, Lubsen $H$, Van der Tweel I, Hilgers FJM, Eijkenboom WMH, Marres HAM, Tjho-Heslinga RR, De Jong JMA, Roodenburg JI N: Salivary gland carcinoma: independent prognostic factors for locoregional control, distant metastases, and overall survival: results of the Dutch head and neck oncology cooperative group. Head Neck 2004, 26:681-693.

157. Andry G, Hamoir M, Locati LD, Licitra L, Langendijk JA: Management of salivary gland tumors. Expert Rev Anticancer Ther 2012, 12:1161-1168.

158. Chen AM, Garcia J, Lee NY, Bucci MK, Eisele DW: Patterns of nodal relapse after surgery and postoperative radiation therapy for carcinomas of the major and minor salivary glands: What is the role of elective neck irradiation? Int J Radiat Oncol 2007, 67:988-994.

159. Armstrong JG, Harrison LB, Thaler HT, Friedlander-Klar H, Fass DE, Zelefsky MJ, Shah JP, Strong EW, Spiro RH: The indications for elective treatment of the neck in cancer of the major salivary glands. Cancer 1992, 69:615-619. 
160. Zbären $P$, Schüpbach J, Nuyens M, Stauffer $E$, Greiner R, Häusler R: Carcinoma of the parotid gland. Am J Surg 2003, 186:57-62.

161. Jones AS, Cook JA, Phillips DE, Roland NR: Squamous carcinoma presenting as an enlarged cervical lymph node. Cancer 1993, 72:1756-1761.

162. Goldenberg D, Begum S, Westra WH, Khan Z, Sciubba J, Pai SI, Califano JA, Tufano RP, Koch WM: Cystic lymph node metastasis in patients with head and neck cancer: An HPV-associated phenomenon. Head Neck 2008, 30:898-903.

163. Mendenhall WM, Mancuso AA, Parsons JT, Stringer SP, Cassisi NJ: Diagnostic evaluation of squamous cell carcinoma metastatic to cervical lymph nodes from an unknown head and neck primary site. Head Neck 1998, 20:739-744

164. Nieder C, Gregoire V, Ang KK: Cervical lymph node metastases from occult squamous cell carcinoma: cut down a tree to get an apple? Int $J$ Radiat Oncol 2001, 50:727-733.

165. Koch WM, Bhatti N, Williams MF, Eisele DW: Oncologic rationale for bilateral tonsillectomy in head and neck squamous cell carcinoma of unknown primary source. Otolaryngol-Head Neck Surg Off J Am Acad Otolaryngol-Head Neck Surg 2001, 124:331-333.

166. Kinder KJ, Lavertu P, Yao M: Positron emission tomography in head and neck squamous cell carcinoma of unknown primary. PET Clin 2012, 7:443-452.

167. Safa AA, Tran LM, Rege S, Brown CV, Mandelkern MA, Wang MB, Sadeghi A, Juillard G: The role of positron emission tomography in occult primary head and neck cancers. Cancer J Sci Am 1999, 5:214-218.

168. Frank SJ, Rosenthal DI, Petsuksiri J, Ang KK, Morrison WH, Weber RS, Glisson BS, Chao KSC, Schwartz DL, Chronowski GM, El-Naggar AK, Garden AS: Intensity-modulated radiotherapy for cervical node squamous cell carcinoma metastases from unknown head-and-neck primary site: M. D. Anderson cancer center outcomes and patterns of failure. Int J Radiat Oncol 2010, 78:1005-1010.

169. Riaz N, Chen A, Lee NY: Squamous cell carcinoma of unknown primary in the head and neck. In Target Vol Delin Field Setup. Edited by Lee NY, Lu JJ. Berlin Heidelberg: Springer; 2013:65-71.

170. Beldì D, Jereczek-Fossa BA, D'Onofrio A, Gambaro G, Fiore MR, Pia F, Chiesa F, Orecchia R, Krengli M: Role of radiotherapy in the treatment of cervical lymph node metastases from an unknown primary site: retrospective analysis of 113 patients. Int J Radiat Oncol 2007, 69:1051-1058.

171. Mendenhall WM, Mancuso AA, Amdur RJ, Stringer SP, Villaret DB, Cassisi NJ: Squamous cell carcinoma metastatic to the neck from an unknown head and neck primary site. Am J Otolaryngol 2001, 22:261-267.

172. Villeneuve H, Després P, Fortin B, Filion E, Donath D, Soulières D, Guertin L, Ayad T, Christopoulos A, Nguyen-Tan PF: Cervical lymph node metastases from unknown primary cancer: a single-institution experience with intensity-modulated radiotherapy. Int J Radiat Oncol 2012, 82:1866-1871.

173. Shoushtari A, Saylor D, Kerr K-L, Sheng K, Thomas C, Jameson M, Reibel J, Shonka D, Levine P, Read P: Outcomes of patients with head-and-neck cancer of unknown primary origin treated with intensity-modulated radiotherapy. Int J Radiat Oncol 2011, 81:e83-e91.

174. Ligey A, Gentil J, Créhange G, Montbarbon X, Pommier P, Peignaux K, Truc G, Maingon P: Impact of target volumes and radiation technique on loco-regional control and survival for patients with unilateral cervical lymph node metastases from an unknown primary. Radiother Oncol 2009, 93:483-487

\section{Submit your next manuscript to BioMed Central and take full advantage of:}

- Convenient online submission

- Thorough peer review

- No space constraints or color figure charges

- Immediate publication on acceptance

- Inclusion in PubMed, CAS, Scopus and Google Scholar

- Research which is freely available for redistribution 